\title{
The contribution of immigration from Ukraine to economic growth in Poland
}

\author{
Paweł Strzelecki ${ }^{1}$ (1) J Jakub Growiec ${ }^{1}(1) \cdot$ Robert Wyszyński $^{2}(0)$
}

Accepted: 6 August 2021 / Published online: 20 September 2021

(c) The Author(s) 2021

\begin{abstract}
From 2014 onwards Poland witnessed an unprecedented inflow of immigrant workers from Ukraine. Coupled with strong labour demand, this surge in labour supply provided a major contribution to Poland's economic growth. However, due to problems with capturing immigration in Labour Force Survey data this contribution has remained hitherto largely unaccounted in official data. This paper uses a range of alternative official data sources to estimate the actual number of immigrants, and survey data on migrant characteristics, collected in four Polish cities, to estimate the effective labour supply of Ukrainian immigrants in terms of productivity-adjusted hours worked. The authors find that the arrival of Ukrainian workers was increasing the effective labour supply in Poland in $2013-2018$ by $0.8 \%$ per annum. Imputing this additional labour supply in a growth accounting exercise they find that the (previously unaccounted) contribution of Ukrainian workers amounted to about 0.5 pp. per annum, i.e., about 13\% of Poland's GDP growth in 2013-2018. The same figure should be subtracted from the residual contribution of total factor productivity growth, suggesting that recent growth in Poland has been in fact much more labourintensive than previously interpreted.
\end{abstract}

Keywords Growth accounting · Immigration · Labour input · Poland · Ukraine

JEL Classification E24 · O47 · F22 - O15

\begin{abstract}
The views presented in this paper belong to the authors only and have not been endorsed by NBP. All errors are our responsibility. The authors would like to thank colleagues from the Department of Economic Analysis and Department of Statistics of NBP for the consultations regarding the methods of estimating the number of immigrants employed in Poland. We are also grateful for many inspiring comments from participants of the NBP research seminar where the draft version of this paper was initially presented, as well as the helpful suggestions of two anonymous referees which helped substantially improve the paper.
\end{abstract}

Paweł Strzelecki

pawel.strzelecki@sgh.waw.pl

1 Narodowy Bank Polski and SGH Warsaw School of Economics, Warszawa, Poland

2 Narodowy Bank Polski, Warszawa, Poland 


\section{Introduction}

Poland is a converging country. Its catch-up process with Western Europe began around 1992, after the preceding turbulent transition period, and over the next decades it was fueled by rapid capital accumulation, systematic improvements in the educational attainment of the Polish population as well as technology transfer and institutional convergence in the run-up and after Poland's accession to the European Union in 2004. Despite great improvements, though, until 2013 Poland remained an emigration country. About 1.2 million Poles (3\% of the population) left the country between 2002 and 2013, with a particularly remarkable wave of 0.7 million emigrants to the United Kingdom and Ireland in 2004-2008. ${ }^{1}$

This situation reversed abruptly in 2014. From that year onward Poland admitted probably between one and two million immigrants from Ukraine (Fig. 1). ${ }^{2}$ This wave of immigration, of an unprecedented scale in Poland's modern history, was significant also from the European perspective. In particular "in 2018, one out of five first residence permits was issued in Poland $(635,000$, or $20 \%$ of total permits issued in the EU)", and conversely "citizens of Ukraine (527,000 beneficiaries, of which almost $78 \%$ in Poland) continued to receive the highest number of permits in the EU" (Eurostat 2019). In the years 2016-2018 Poland was also the top OECD destination for temporary labour immigrants (OECD 2020). A vast majority of Ukrainian immigrants arrived in Poland for economic reasons, and they immediately sought (and most of them found) employment here. Their immigration was prompted inter alia by strong labour demand, relatively easy short-term work and residence permits (pull factors) as well as the Russian aggression on Ukraine in 2014 with an ensuing economic crisis there (push factors). In contrast to migrants from Ukraine to Poland before 2014-less than 0.2 million of mostly temporary workers in the agricultural sector-the new immigrants located predominantly in cities and sought work across a broad spectrum of economic sectors.

Unfortunately, this massive inflow of Ukrainian workers was only marginally reflected in official Labour Force Survey (LFS) data. This is partly due to definition problems - only migrants staying longer than one year are included in the LFS, whereas the (renewable) legal period of stay based on so-called invitations is typically 6-9 months. Furthermore, immigrants are also statistically less likely to participate in surveys than natives.

Crucially, however, this omission-regardless of its causes-has stark consequences for economic growth decompositions using LFS data. The failure to include

\footnotetext{
1 Emigration before 2002 was also substantial but the estimates are not provided by Statistics Poland. Furthermore, negative net migration of Polish citizens - though not as large- has been observed also after 2013.

2 Immigration from other countries was of lesser importance and did not record such a dramatic surge. According to Polish Social Security Institution (ZUS) data, citizens of all other countries excluding Ukraine constituted about one fourth of foreign contribution payers in 2019. While the number of Ukrainians paying their social contributions to the Polish social security system was increasing at an average pace of $33 \% \mathrm{y} / \mathrm{y}$ in 2014 and about $92 \% \mathrm{y} / \mathrm{y}$ in the years 2015-2016, the number of contributors from other countries accelerated only after $2016 \mathrm{H} 2$.
} 


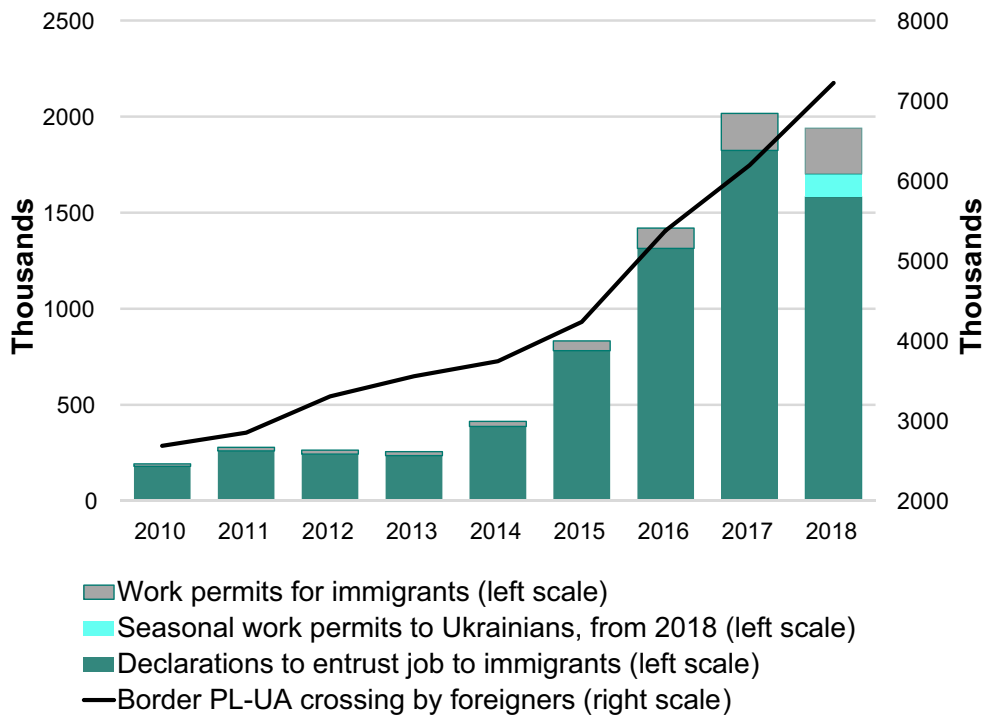

Fig. 1 The scale of immigration to Poland from Ukraine according to different data sources Source: Ministry of Labour, Polish Border Guard data. Notes: The numbers for 2018 are not fully comparable with earlier data because of the introduction of an amendment to the Act on Employment Promotion and Labour Market Institutions, which changed the immigration law in Poland in two ways. First, declarations of employers planning to hire foreigners ceased to be only declarations of intention and became declarations on entrusting work. This eliminated unused declarations. Second, seasonal work permits were introduced, issued for a period of up to 9 months and acquired by employers planning to hire a foreigner in agriculture, horticulture, tourist industry and other activities considered seasonal

the inflow of immigrants in estimates of labour supply implies underestimation of growth in the number of workers and total hours worked in the economy and subsequent overestimation of growth in (residual) total factor productivity (TFP). This is a problem that needs to be fixed or otherwise our estimates of sources of economic growth in Poland-and, on principle, anywhere where immigrants are not included in the official calculation of labour supply—will be systematically biased.

The contribution of the current paper is to impute the labour of immigrant workers from Ukraine-measured in terms of productivity-adjusted hours workedto the official LFS labour supply data for Poland which essentially represents the labour of Poles. To this end we first construct an estimate of the actual number of immigrants, using a variety of auxiliary sources from the Ministry of Labour, Ministry of Foreign Affairs, the Polish Social Security Institution (ZUS) and the Border Guard, each providing different partial information. Second, to obtain a precise estimate of the productivity-adjusted labour supply of immigrant workers we use information on their hours worked and worker characteristics, allowing us to identify their productivity. We obtain this information from survey datasets on migrant characteristics, collected by NBP among Ukrainians residing in four Polish cities: 
Warsaw, Lublin, Wrocław and Bydgoszcz (Chmielewska et al. 2019). The data suggest that migrants, compared to the natives, are characterized by more hours worked on average but greater concentration in low-skill, low-wage jobs. In particular, they are often employed in occupations below their formal education level (brain waste). They are also often remunerated less at equal occupations and with prima facie equal skills (Strzelecki 2018), either due to wage discrimination or unmeasured differences between labour productivity and employment costs, which may reflect, e.g., instability of contracts, lower firm- and task-specific human capital, imperfect applicability of knowledge gained abroad to nominally the same occupations in the host country, or linguistic barriers to communication. In the final step, we plug our imputations into a standard growth accounting procedure and thereby identify the contribution of Ukrainian workers to GDP growth in Poland.

In our baseline case, we find that in 2013-18 the arrival of migrant workers from Ukraine increased growth in the effective labour supply in Poland by $0.8 \%$ per annum on average. Based on this imputation we infer that the (previously unaccounted) contribution of Ukrainian workers to Poland's GDP growth in 2013-2018 amounted to $0.5 \mathrm{pp}$. per annum on average, or about $13 \%$ of total growth. The same figure should be subtracted from the residual contribution of TFP growth, suggesting that recent growth in Poland has been much more labour-intensive than previously interpreted.

As the estimation of magnitude and structure of migration is fraught with uncertainty, we pursue extensive robustness checks of our results. We consider a range of alternative scenarios, making different assumptions regarding the number of migrants, their average hours worked and structure in terms of observable characteristics. This generates a fan chart of possible effects of immigration around the baseline scenario.

The remainder of the paper is structured as follows. Section 2 discusses the associated literature, referring in particular to the available estimates of the contribution of immigrant workers to GDP growth in other countries (e.g., of Polish immigrants to the UK). Section 3 presents the empirical methodology and discusses the data sources. Section 4 handles the uncertainty in measurement of migration by considering a range of alternative scenarios. Section 5 presents the main results. Section 6 concludes. Robustness checks and supplementary tables are included in the "Appendix".

\section{Immigrant workers and economic growth}

It is unquestionable that additional immigrant workers contribute to higher total output in the host country. However, the effects of immigration for output per capita and labour productivity are ex ante ambiguous and may depend on a range of factors.

First-order effects are twofold. First, immigration increases the total population in the host country and, as can be easily seen from the standard Solow model (Solow 1956; Barro and Sala-i Martin 1995), increasing population ceteris paribus contributes negatively to per capita growth due to decreasing marginal factor productivity and the dilution of capital. Second, the impact of immigration on labour productivity 
depends also on the productivity of immigrants as represented by their human capital or skill levels (Ehrlich and Kim 2015; Borjas 2019). Theoretical works which apply the human capital augmented Solow model to the context of immigration (e.g., Dolado et al. 1994) conclude that the more immigrants are skilled the more attenuated will be the negative contribution of migration inflow to growth as compared to the natural increase in population. This result has been confirmed empirically (see e.g., Ortega and Peri 2009). In particular, Boubtane et al. (2016) have shown for 22 OECD countries that the positive contribution of permanent immigrants to human capital accumulation in the host country tends to dominate the negative capital dilution effect, even though immigrant workers upon arrival tend to be less productive on average and earn lower wages than natives.

There are also important second order effects. First, the inflow of immigrants creates the so-called immigration surplus: as the equilibrium on the labour market is shifted towards lower wages and higher labour supply, firms' gains from immigration tend to exceed workers' losses and the surplus is redistributed in the host economy (Borjas 1995). ${ }^{3}$ Second, immigrants may promote specialization, increase competition in the labour market and bring new ideas, increasing total factor productivity (TFP, Ottaviano and Peri 2008). In contrast, though, immigration may also cause firms to adopt less productive technologies which require more unskilled labour (or otherwise postpone the adoption of labour-saving, productivity-enhancing innovations, cf. Lewis 2005). Capturing the heterogeneity of immigrants' human capital and the utilization of their skills in the economy is therefore crucial for obtaining a reliable estimate of their impact on GDP growth.

Third, the inflow of immigrants may not just nurture technological innovation, but also- on the negative side-undermine social cohesion and create coordination and communication barriers. Using international data on bilateral migration stocks, Bove and Elia (2017) find that positive innovation and productivity effects systematically prevail, though, and increases in ethnic fractionalization due to foreign immigration tend to have a positive impact on real GDP per capita (see also Alesina et al. 2016).

Finally, immigrants may theoretically also substitute natives in the workforce (see e.g. Chiswick et al. 1985), pushing them out of the labour market and increasing unemployment. Empirical evidence firmly rejects this hypothesis, though. Even in jobs where the elasticity of substitution between native and immigrant workers is high the impact of immigration on wages and unemployment among the natives tends to be relatively low (Friedberg and Hunt 1995). In the OECD there is no Granger causality between the inflow of immigrants and unemployment (Boubtane et al. 2013). In the context of this article, it means that we should reasonably expect that the additional workforce of Ukrainian immigrants arriving in Poland since 2014 should have only marginally displaced the Poles, and therefore the additional labour input growth should trace immigration almost one-to-one. The historically low unemployment rate in Poland and very high labour demand in 2014-2018 confirm this expectation.

\footnotetext{
${ }^{3}$ General equlibrium effects related in particular to the use of capital, distribution of wages and unemployment in the economy, may overturn this result, though (Chojnicki et al. 2011).
} 
The growth accounting procedure used in this paper is a conventional tool for quantitative assessment of the influence of immigration on economic growth in the host country. However, such assessment requires to handle several methodological issues regarding, e.g., the treatment of the composition of migrants in terms of age, gender, education or occupation or the utilization of their skills in the host countries.

Directly comparable publications focusing on the impact of immigration on growth in the host country are rather scarce. Barrell et al. (2010) estimate, based on a large-scale international economic model NiGEL that simulates the consequences of shifts in the number of employees who moved between EU countries, that after the two rounds of EU enlargement in 2004 and 2007 the economies of Ireland and the UK gained from the inflow of immigrants from Central and Eastern European Countries about $1.66 \%$ and $0.64 \%$ of their respective GDP. Aleksynska and Tritah (2015) use a panel of 20 developed OECD countries in 1965-2005 to assess the contribution of foreign immigrants to income of the host countries. Their result is that a $1 \mathrm{pp}$. increase in the share of immigrants in the working-age population has a highly significant positive effect of about $0.18 \mathrm{pp}$. in terms of a country's GDP per worker, and $0.12 \mathrm{pp}$. in terms of its TFP. Similarly, Jaumotte et al. (2016) use a panel dataset on migrants to 18 developed OECD countries in 1980-2010 and estimated the impact of migration on the level of GDP per capita. They find that a $1 \mathrm{pp}$. increase in the share of migrants in the adult population can raise GDP per capita by up to $2 \%$ in the long run. Both high- and low-skilled migrants contribute, and the gains from immigration appear to be broadly shared.

Accordingly, using a panel of 22 OECD countries in 1986-2006 Boubtane et al. (2016) find that a 50\% increase in foreign-born net migration generates, on average, a short-run increase in GDP per worker of 0.3 pp. per annum, which cumulates to about $2 \%$ in the long run. In contrast, Kangasniemi et al. (2012), using an industrylevel dataset for Spain and UK in 1996-2005, find that immigration had a slightly negative contribution to GDP per capita growth in the UK and a sizeable negative contribution in Spain. In both countries, the result was driven by the fact that immigrants had, on average, lower hourly productivity than natives, which outweighed the positive contribution of the fact that immigrants tend to work longer hours. Also, Kane and Rutledge (2018), who use state-level data for the USA in 1980-2015, find moderately negative effects of growth in the foreign-born share of the labour force on GDP and per-capita GDP growth, which however dissipate in level regressions that assess longer-term impacts.

\section{Method and data}

In the current study we first estimate the number of Ukrainian immigrants arriving in Poland over the last decade, then we approximate their productivity-adjusted hours worked, and finally, we plug these estimates into a growth accounting exercise. For expositional purposes, though, it is convenient to present our methodology in reverse order. 


\subsection{Growth accounting}

The methodology of our growth accounting exercise follows Fernald (2012a, b) and Gradzewicz et al. (2018). We carry out decompositions of the constant-returns-toscale aggregate production function

$$
Y=A \cdot F\left(U t i l_{K} \cdot K\left(K_{1}, K_{2}, \ldots, K_{n}\right), U t i l_{L} \cdot L\left(L_{1}, L_{2}, \ldots, L_{m}\right)\right),
$$

based on data on output (i.e. real GDP in base prices as of 2005) of the Polish economy $Y$ as well as the flows of services of inputs: capital $K$ and labour $L$. Each of these two inputs is itself an aggregate of a number of capital or labour types ( $n$ and $m$ types, respectively), differing in their marginal productivity. Flows of capital and labour services are assumed to be proportional but not equal to their stocks. The (time-varying) coefficients of proportionality are the capital and labour utilization rates, denoted as $U t i l_{K}$ and $U t i l_{L}$, respectively. The aggregate production function is augmented with a Hicks-neutral technological change component $A$, interpreted as total factor productivity (TFP) adjusted for capacity utilization.

Having denoted the growth rates of the respective variables as $\hat{x}=\ln \left(\frac{x_{t+1}}{x_{t}}\right)$, the Törnqvist index of output growth is written down as follows: ${ }^{4}$

$$
\hat{Y}=\alpha \hat{K}+(1-\alpha) \hat{L}+\widehat{U t i l}+\hat{A},
$$

where the growth rate of the capital input (services provided by capital) is given by $\hat{K}=c_{1}^{K} \hat{K}_{1}+c_{2}^{K} \hat{K}_{2}+\ldots+c_{n}^{K} \hat{K}_{n}$, the growth rate of the labour input (labour services) is $\hat{L}=c_{1}^{L} \hat{L}_{1}+c_{2}^{L} \hat{L}_{2}+\ldots+c_{m}^{L} \hat{L}_{m}$, and $\widehat{\text { Util }}=\alpha \widehat{\text { Util }_{K}}+(1-\alpha) \widehat{\text { Util }} L$ is the weighted average of capital and labour utilization rates. In accordance with the generality of the above Törnqvist index, allowing us to refrain from making exact functional assumptions on the aggregate production function, the components of input aggregates are weighted proportionally to their (time-varying) shares in total remuneration of the respective inputs: $c_{i}^{K}$ is the share of remuneration of $K_{i}$ in $K, c_{i}^{L}$ is the share of remuneration of $L_{i}$ in $L, \alpha$ is the capital share of GDP at factor prices. ${ }^{5}$ Each of these shares is computed as an arithmetic average of the respective values at times $t$ and $t+1$.

Having backed out the contributions of increases in capital and labour services to GDP growth, we are left with TFP (or Solow residual), which can be further decomposed into two components: the relative change in capacity utilization and a capacity utilization-adjusted measure of TFP growth:

$$
\widehat{T F P}=\hat{Y}-\alpha \hat{K}-(1-\alpha) \hat{L}=\widehat{U t i l}+\hat{A} .
$$

\footnotetext{
${ }^{4}$ See Hulten (2009) for a broad overview of growth accounting methods.

5 The capital share of GDP is computed based on annual data on GDP at factor prices, gross operating surplus, total compensation of employees, and gross mixed income. We assume that mixed income of proprietors is split into the remuneration of capital and labour in the same proportion as in the rest of the economy. In Poland, the capital income share has exhibited a sharp increase in 2001-04 (from approx. $31 \%$ to 39\%) after which it has remained roughly constant at the elevated level until 2018.
} 
TFP growth can be viewed as a difference between growth in output and inputs. However, due to being a residual component, it is also a term where all possible 'other factors' show up: measurement error, time-varying markups, variation in inventories, etc.

Our output growth decomposition rests on the usual set of neoclassical assumptions. Firms in our setup are requested to maximize their profits, with the implication that marginal products are proportional to marginal costs of production. The setup allows for the existence of markups over marginal costs of capital and labour; yet, for the measurement to be consistent, these markups ought to be constant over time.

\subsection{The labour composition component}

The aggregation procedure used in our study takes into account the differences in unit productivity across the considered capital and labour types, and therefore it should be clearly distinguished from simple summation. Denoting the raw sum of capital inputs as $K_{\text {raw }}=K_{1}+K_{2}+\ldots+K_{n}$ and the raw sum of hours worked in the economy as $L_{\text {raw }}=L_{1}+L_{2}+\ldots+L_{m}$, we define growth in the composition component of capital and labour, respectively, as

$$
\hat{Q}_{K}=\hat{K}-\hat{K}_{\text {raw }}, \quad \hat{Q}_{L}=\hat{L}-\hat{L}_{\text {raw }} .
$$

Given that growth in the capital composition component has been essentially zero in Poland since 2000 (Gradzewicz et al. 2018) and the focus of the current paper is on labour, in the following paragraphs we will discuss exclusively the labour composition component, $Q_{L}$.

Growth in the labour composition component, i.e. the difference between productivity-weighted and unweighted hours worked, captures the dynamic effects of shifts in shares of various types of labour in its total remuneration. More precisely, any increase in the labour composition component should be interpreted as an indication of an observed increase in the share of relatively more productive labour types in the raw labour aggregate. The labour composition component may rise, for instance, due to an increase in the share of (relatively more productive) people with tertiary education in the workforce.

Until 2013 changes in labour composition were the second most important contributor to output growth in Poland, topped only by the accumulation of physical capital. The prime source of this contribution was the massive increase in educational attainment among the Polish population over the last decades. Other considered dimensions of heterogeneity of workers in the Polish LFS-age, gender and sector-were much less potent (Gradzewicz et al. 2018). In the current research we add to that idea in two ways. First, we add citizenship (Polish or Ukrainian) as an additional dimension of stratification. Second, we observe that in the context of defining the status of Ukrainian immigrants on the Polish labour market it is also important to take occupations into account. So in order to measure heterogeneity of workers and hours worked, we stratify workers by their educational attainment, age, 
gender, sector and occupation. This allows us to draw a clear distinction between raw measures of the labour input (employment, hours worked) and our main variable of interest: the actual flow of labour services, corrected for the differences in labour productivity across employees and workplaces.

More precisely, our approach to capturing changes in labour composition follows Bell et al. (2005). It is based on the estimation of means for each of the considered groups of workers. We assume that the growth rate of the productivity-adjusted labour input is given by the following Törnqvist index:

$$
\hat{L}_{t}=\Delta \ln L_{t}=\sum_{i=1}^{m}\left(\frac{s_{i, t}+s_{i, t-1}}{2}\right) \ln \left(\frac{h_{i, t}}{h_{i, t-1}}\right),
$$

where $h_{i, t}$ represents hours worked by workers from group $i$ at time $t$ and $s_{i, t}$ is the share of labour compensation of group $i$ at time $t$. The weights in the index are given by average shares in the periods $t$ and $t-1$. Growth rates of the composition-adjusted labour input are then obtained as a weighted average of growth rates of total hours worked by groups of workers, with weights given by their respective shares in total labour compensation. Hence, the productivity-adjusted index grows faster than the unadjusted one if and only if the groups with relatively higher wages experience relatively faster growth in hours worked.

The growth rate of the unadjusted labour input, on the other hand, captures the dynamics of the total number of hours worked, $\hat{L}_{r a w}=\Delta \ln H_{t}$, treating all hours worked as homogeneous. It can also be further decomposed into the growth rate of employment $\Delta \ln E_{t}$ (the extensive margin) and the growth rate of average hours worked per worker $\Delta \ln \bar{H}_{t}$ (the intensive margin). Finally, the difference between the growth rates of the productivity-adjusted and unadjusted labour input captures the the contribution of the labour composition component ('quality' of hours worked):

$$
\hat{Q}_{L}=\Delta \ln Q_{t}=\Delta \ln L_{t}-\Delta \ln H_{t}=\Delta \ln L_{t}-\Delta \ln \bar{H}_{t}-\Delta \ln E_{t} .
$$

Using the properties of the Törnqvist index, we also calculate the separate contributions of each of the worker features taken into account (citizenship, educational attainment, age, gender, sector, occupation) to the growth of the productivityadjusted labour input. For example, the partial 'education-specific' labour composition component, capturing the differences between groups according to their educational attainment but ignoring all other dimensions of worker heterogeneity, is computed as:

$$
\Delta \ln Q_{t}^{E d u}=\Delta \ln L_{t}^{E d u}-\Delta \ln H_{t} .
$$

This is called a first order partial index of characteristic $i$. Since the current study singles out six distinct labour force characteristics, we compute six partial indexes of this kind. Among them, of particular interest to the current paper is the decomposition of labour input growth into the contributions of native and immigrant workers:

$$
\hat{L}=\hat{L}^{P L}+\hat{L}^{U A}=\hat{L}_{\text {raw }}^{P L}+\hat{L}_{\text {raw }}^{U A}+\hat{Q}_{L}^{P L}+\hat{Q}_{L}^{U A} .
$$


In principle, one could also consider individual contributions of combinations of (two or more) worker features, leading to the calculation of second-and higher-order labour force productivity decompositions. However, they are of relatively minor importance for the results of the current study and thus we set them aside.

\subsection{Data sources}

We use Polish Labour Force Survey (LFS) microdata from Statistics Poland to describe the size and characteristics of employment of Polish citizens. This dataset contains representative and most comprehensive information regarding the labour market in Poland in the period 1995-2018. The quarterly sample size in the LFS varies between 50 and 100 thousand individuals (Statistics Poland 2018). Unfortunately, information about individual wages needs to be interpolated as some persons answer only categorical questions about their income and some refuse to answer this question completely.

In spite of the value of LFS as a source of information about native workers, it covers only a minor part of the immigrants who live and work in Poland. This is because by definition the LFS survey is addressed to persons who live in Poland for at least one year while majority of immigrants stay in Poland for shorter periods only because of the most popular short-term visas. According to both Ukrainian sources and Polish surveys only about $6 \%$ of immigrants from Ukraine had longtime work contracts in the beginning of 2017 (Chmielewska et al. 2018). Another reason for the absence of immigrants in the Polish LFS is their geographical mobility (even if migrants stay in Poland long enough to be included they relatively frequently change their place of residence) and reluctance to participate in surveys, as well as a relatively high incidence of living in collective households, which are in practice excluded from the LFS. In the period 2014-16 in Polish LFS there were only 82 immigrants who filled the questionnaire including the information on their wages and hours worked. At the same time the number of immigrants observed in the Polish economy increased to around one million, so proportionally hundreds of immigrants should have been observed in every quarter of the sample of a study as big as LFS. ${ }^{6}$ It is therefore clear that Ukrainian immigrants are largely underrepresented in LFS. To impute them we use other available official data sources.

Although there is no one comprehensive dataset on immigrants to Poland, the requisite information can be recovered from a variety of fractional data sources

\footnotetext{
${ }^{6}$ Increased immigration is only one of the phenomena that have influenced the labour market in Poland since 1995 but are not fully reflected in the LFS. The remaining two are changes due to population aging and emigration of Polish workers after the EU accession. In both cases the censuses in 2002 and in 2011 allowed to adjust the population size and structure used to weight LFS results but the adjustments have been done only to few years and not the entire period between censuses. Another problem are the discontinuities caused by methodological changes. The underestimation of emigration of Polish citizens in the Labour Force Survey data published before 2010 has been caused by the imperfect definition of migrants used by Statistics Poland in the past. This has been corrected after the census in 2011 and now the definition (consistent with Eurostat requirements) should reflect the changes of the number of emigrants. However, the data have not been corrected backward before 2010 in Statistics Poland and Eurostat publications. In this paper we use the most reliable estimates of the necessary corrections of LFS data (Saczuk 2014) to correct the weights of the LFS datasets.
} 
capturing different aspects of migration, with different coverage and definitional caveats. In order to estimate the true number of immigrant workers in Poland as close as possible, one should be aware of all their strengths, drawbacks and specificities.

We use the following datasets. First, raw data published by Ministry of Labour (see Fig. 1) refers to the number of declarations on entrusting work to foreign workers as well as to work permits issued during the year. Not all declarations, however, end with an employment contract. One immigrant is also allowed to receive declarations from several different employers. Moreover, the average duration of work on the basis of such a declaration amounts by definition only to half a year. This is why that measure strongly overestimates the effective headcount of immigrants and needs to be corrected in order to reflect reliably the immigrant labour force. Second, Polish Border Guard data on border crossings constitute another publicly accessible source of information about the intensity of migration movements. They complete the picture of immigration flows to Poland, while contributing to the assessment of tendencies, although they are hardly applicable to identify the scale of migration which is predominantly circular. Third, another useful data source is the number of foreign citizens paying their social contributions to the Polish social security system. The share of short-term migrants in Poland covered by the Polish Social Security Institution (ZUS) is systematically increasing. Nonetheless, the share of foreign citizens working on the basis of civil law contracts not covered by ZUS, especially those combined with employer's declarations, remains relatively high, which makes the calculation of immigrants based exclusively on that data source still incomplete $^{7}$. Fourth, according to Statistics Poland estimates based on the capture-recapture method applied to selected micro databases that contain the information about immigrants (Szałtys et al. 2018) the number of immigrants in Poland amounted to 488 thousand at the end of 2015 and 720 thousand at the end of 2016. The width of $95 \%$ confidence intervals for these estimates (between 355 and 699 thousand in 2015 and between 580 and 915 thousand in 2016), however, underscores the high uncertainty in analyzing migration flows. Apart from wide confidence intervals the problem with this estimate is that Statistics Poland focuses on the population at the end of the year but what matters from the perspective of economic growth is the average number of persons during the year who are active on the Polish labour market. For all these reasons, we treat these sources as only auxiliary and proceed to construct our own estimates of the number of Ukrainian immigrants in Poland.

Our information on the socio-demographic structure of immigrants from Ukraine comes from immigrant surveys carried out by NBP using respondent-driven sampling (RDS) in selected cities in Poland: Warsaw, Lublin, Bydgoszcz and Wrocław (Table 1). In total 1920 interviews have been carried out but only 1536 of them covered employed persons who answered all questions about wages, hours worked, personal characteristics (gender, age, educational level) and description of the

\footnotetext{
7 According to ZUS data the number of foreign citizens paying their social contributions to the Polish security system was 644 thousand, of which 483 thousand Ukrainians as of 30 June 2019.
} 
Table 1 Description of samples of immigrant surveys

\begin{tabular}{lcccc}
\hline & Warsaw & Lublin & Bydgoszcz & Wrocław \\
\hline Year & 2015 & 2016 & 2018 & 2018 \\
Sample size & 710 & 400 & 310 & 500 \\
Effective sample size & 540 & 310 & 297 & 389 \\
\hline
\end{tabular}

Source: Own calculations

workplace (economic sector, occupation). ${ }^{8}$ RDS was used in order to cope with the important problem that for short-term immigrants the sampling frame is not available (Heckathorn 1997). ${ }^{9}$ Naturally, the representativeness of data from selected places in Poland for the entire population of Ukrainians in Poland can be legitimately questioned, but better data are not available and at least we know that since 2014 a large fraction of the new immigration is observed in the sectors highly present in big cities while the share of agriculture is declining (see Fig. 1). In our assessment, the information obtained from the NBP survey dataset is comprehensive enough to create the profiles of hours worked and wages required in the analysis but is insufficient to reconstruct the dynamics of these indicators over time, in which case the sample size would become too small in comparison to the required cross-tabulations. That is why in our analysis we calculate hours worked and hourly wages of immigrants for pooled data only and assume that these profiles have been constant over time.

Unfortunately, application of publicly available data regarding the structural characteristics of immigrants was not possible because the requisite information (like the cross-tabulations by gender, educational attainment or occupation) was unavailable. Reassuringly, though, available official data from ZUS are broadly consistent with NBP survey estimates, whereas data from the Ministry of Labour exhibit explainable differences (see Table 2). The key ambiguity pertains to the share of employment in agriculture which is very sensitive to the time-varying institutional setup, ${ }^{10}$

\footnotetext{
${ }^{8}$ Information about workplaces has been collected from descriptive questions in order to avoid misunderstandings which are frequent when using the official classification of occupations and sectors. However information collected from the survey was sufficient to recode answers to the official classification in the database.

${ }^{9}$ RDS allows to control the process of recruitment of respondents and create weights to balance the results. In addition the method of conducting the interviews assures the best possible conditions to collect unbiased information on sensitive issues by: ensuring anonymity, using safe places outside immigrants' work or households, translating questionnaires to the native language of immigrants, paying small amounts of money for the time spent on the interview and helping in further recruitment.

10 The data of the Ministry of Labour in 2016, compiled before creating a separate category of seasonal work, contained a lot of declarations to entrust jobs to immigrants in the agriculture sector (about $35 \%$ of all declarations). However, only about $60 \%$ of these declarations have been converted into jobs (Górny et al. 2018, p. 27) and one single declaration allowed work for a maximum period of half of the year, so that to be employed for the entire year at least two declarations were needed. After the reform, by contrast, in 2018 almost all documents that enabled work in agriculture sector were seasonal work permits. However this new category was very different from documents used previously (only very short-term stays, different procedure of registration) and was not included in the table. That is why employment in agriculture nearly disappeared from the Ministry of Labour data. In turn, data collected by ZUS by definition include only job contracts outside of agriculture.
} 
Table 2 The structure of employment by non-agriculture sectors relative to the non-agriculture total (in \%)

\begin{tabular}{lcccc}
\hline Sector & NBP surveys & ML*(2018) & ML*(2016) & ZUS** (2018) \\
\hline Non-agriculture total & 100 & 100 & 100 & 100 \\
Manufacturing & 23 & 38 & 17 & 15 \\
Construction & 13 & 21 & 17 & 12 \\
Market services & 56 & 38 & 57 & 60 \\
Non-market services & 8 & 3 & 9 & 13 \\
Agriculture*** & 7 & 1 & 55 & - \\
\hline
\end{tabular}

Source: Own calculations based on NBP surveys

* ML Ministry of labour data on work permits and declarations to entrust jobs to immigrants, **ZUS National Insurance Institution data on the contributions of foreign citizens employed in Poland, *** for comparison, agriculture presented as a separate sector and expressed as a percentage of nonagriculture employment

and a discrepancy is also observed with regard to the share of employment in services, owing to a changing role of employment agencies. ${ }^{11}$

The data on Poland's annual GDP, gross fixed capital formation and its breakdown, and factor shares have been taken from Eurostat. The procedure for computing the productivity-adjusted stock of physical capital is exactly the same as in Gradzewicz et al. (2018).

Finally, as short- to medium-run variation in observed TFP growth can be driven by changes in the utilization rate of production factors, we adjust TFP growth with a survey-based measure of capacity utilization, computed by NBP based on its Quick Monitoring Survey (NBP 2019). Consistently with the characteristics of this dataset, we depart from Fernald (2012a) and apply the utilization rate to capital only. Labour utilization rates are, as opposed to Fernald's data, already included in our direct, LFS-based measure of hours worked.

\section{Imputation of immigrant labour supply}

In order to impute the (hitherto unaccounted) labour supply of Ukrainian immigrants to Poland, we need to make firm assumptions on the following issues: (i) the number of immigrant workers, (ii) the structure of hours worked per immigrant worker, and (iii) their productivity.

Unfortunately, there is substantial uncertainty in all three dimensions, and therefore we must consider a number of alternative scenarios. We consider (i) two main

\footnotetext{
11 Due to the introduction of an amendment to the Act on Employment Promotion and Labour Market Institutions in 2018 and EU visa liberalization in 2017 (see Footnote 13), the role of employment agencies has changed. As of 2018, a significant part of those agencies ceased to participate in the "simplified procedure" (Górny et al. 2019, p. 13). In effect, the share of services sector, where employment agencies belong to, decreased significantly in the structure of declarations (Ministry of Labour data).
} 


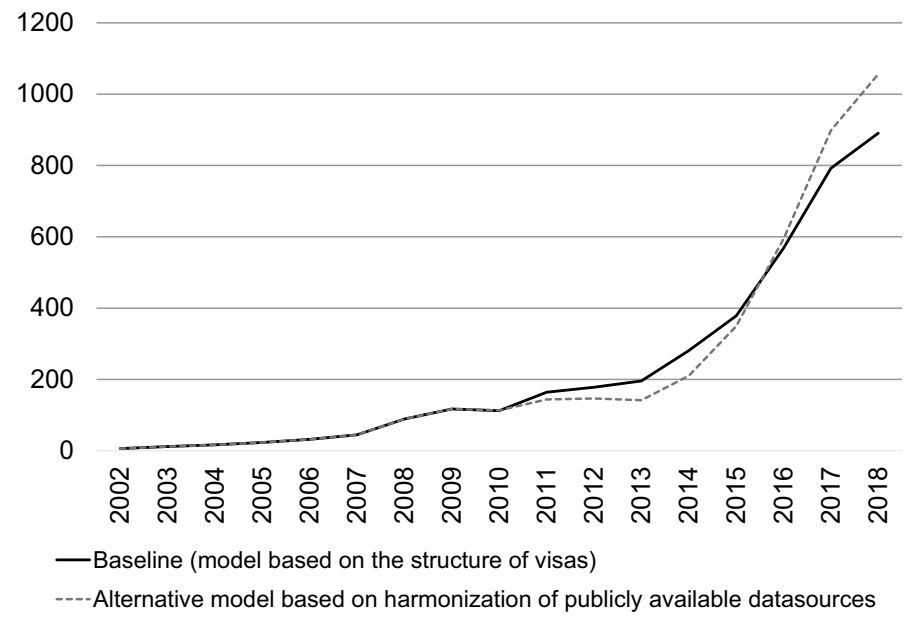

Fig. 2 Comparison of estimates of the average number of employed immigrants from Ukraine in the Polish economy during the year. Source: Own calculations

scenarios (and two additional robustness checks) for the number of immigrant workers, and (ii)-(iii) one main scenario plus four robustness checks for their structure and productivity.

\subsection{Number of immigrant workers}

According to a recent OECD report (OECD 2020) about 1.1 million immigrants were working in Poland in 2018. Similar numbers can be found also in other sources such as NBP communication (DAE-NBP 2019) or a report by Selectivv based on cell phone data (Czubkowska 2019). In this paper, we use two alternative approaches to estimating the average number of immigrants from Ukraine employed in Poland each year. ${ }^{12}$ Aggregate numbers produced by both of them are in the same ballpark (either 0.9 or 1.1 million Ukrainian immigrants in 2018), but there is a noticeable difference in dynamics. Figure 2 presents the comparison of the estimates obtained in our baseline scenario and an alternative one.

In the baseline scenario, the number of Ukrainians has been calculated on the basis of data about the number of different types of visas, residence permits issued to immigrants and additional data on the average time spent by them in Poland taken from survey data (Górny et al. 2018). The advantage of this approach is a reduction of the problem of double counting of the same persons, as both visas and residence permits are always assigned to one single person. Unfortunately this estimate

\footnotetext{
12 It should be emphasised that it is not the total number of immigrants (not all immigrants are employed) or the number of immigrants in a certain moment of the year (due to seasonality it will depend on the choice of month).
} 
is based on the data from the Ministry of Foreign Affairs which is not publicly available. This approach also excludes persons who used to work in Poland illegally either on the basis of tourist visas before EU visa liberalization (June 2017) ${ }^{13}$ or on the basis of a biometric passport (which allows for stays up to 3 months), so it omits this part of illegal employment. Since July 2017 the estimated number of working immigrants from Ukraine has been complemented with immigrants coming within the course of the visa-free regime for the purpose of work, mostly being legally employed on the basis of employer's declaration. In this scenario, we assume that the number of immigrants employed in the Polish economy before 2002 was negligible (only several thousand) but it increased somewhat after 2007 when liberal regulations of employment in agriculture were introduced. After 2013, during the recent surge of immigration, the average annual number of immigrants who work in the Polish economy has increased from nearly 200 thousand in 2013 to almost 900 thousand in 2018. Respectively the share of immigrants in the Polish labour supply has increased from less than 1\% before 2013 to more than 5\% in 2018.

Our alternative scenario is based on the publicly available data about different types of documents that enable Ukrainian citizens to stay in Poland and some assumptions about harmonization of this data (in particular we assume that all persons with work permits regularly pay contributions to ZUS). Here also additional information from surveys is needed in order to define the time of stay and work. This estimate takes into account also formally illegal work (for example of persons entering Poland only with tourist visas or biometric passports). The drawback of this approach is the possibility of double counting of the same persons during the year. According to this estimate, the wave of immigration after 2014 was much sharper and the number of immigrants from Ukraine who worked in Poland in 2018 was close to 1.1 million.

In order to measure the possible consequences of uncertainty in measuring the number of immigrants, we have also added two robustness checks in which the size of immigration is systematically $20 \%$ lower or $20 \%$ higher than the baseline.

\subsection{Heterogeneity of socio-economic features of workers}

The impact of immigrants on economic growth depends on their productivity, which in turn depends on their socio-demographic features and characteristics of their workplaces. In this paper, we stratify immigrants by gender ( 2 groups), age (4 groups), educational attainment ( 3 groups), sector of employment ( 3 groups) and occupation ( 3 groups). Thereby we consider in total $2 \cdot 4 \cdot 3 \cdot 3 \cdot 3=216$ combinations of features, separately for native and immigrant workers. For each of these combinations, we calculate average hours worked and average wage.

General information about the socio-economic features of immigrant and native workers is presented in Table 3. There are significant differences in the proportions

\footnotetext{
13 The decision to transfer Ukraine to the list of third countries whose nationals are exempt from the visa requirement came into effect on 11 June 2017. From this date, the visa obligation for citizens of Ukraine who hold a biometric passport and want to travel to the Schengen zone for a short stay was abolished.
} 
Table 3 Characteristics of immigrant and native workers (in \%)

\begin{tabular}{|c|c|c|c|}
\hline Variable & Immigrants & Natives in 2018 & Natives in 1995 \\
\hline Gender & 100 & 100 & 100 \\
\hline Male & 47 & 53 & 55 \\
\hline Female & 53 & 47 & 45 \\
\hline Age & 100 & 100 & 100 \\
\hline $15-24$ & 36 & 6 & 10 \\
\hline $25-44$ & 53 & 61 & 69 \\
\hline $45-59 / 64$ & 10 & 27 & 15 \\
\hline $60 / 65+$ & 1 & 6 & 5 \\
\hline Educational attainment & 100 & 100 & 100 \\
\hline Tertiary & 51 & 35 & 10 \\
\hline Secondary & 40 & 35 & 33 \\
\hline Primary and basic vocational & 9 & 30 & 57 \\
\hline Sector & 100 & 100 & 100 \\
\hline Industry & 19 & 16 & 31 \\
\hline Agriculture and construction & 22 & 24 & 25 \\
\hline Services & 59 & 59 & 43 \\
\hline Occupation & 100 & 100 & 100 \\
\hline Managers and specialists & 8 & 27 & 14 \\
\hline Middle & 36 & 43 & 45 \\
\hline Bottom & 56 & 30 & 41 \\
\hline
\end{tabular}

Source: Own calculations based on NBP surveys and LFS

of immigrants and native workers with respective characteristics. First, the share of women in the sample of employed immigrants is somewhat higher than in the total population of Polish employees. Second, the immigrants were on average much younger: $36 \%$ of immigrant workers were younger than 25 years compared to only $6 \%$ of Polish employees in 2018. Third, the immigrants were on average better educated: $51 \%$ declared completed tertiary education in comparison to $35 \%$ of the Polish working population in 2018. At the same time, the share of persons with primary and basic vocational attainment among immigrants (9\%) was relatively low compared to Polish employees (30\% in 2018). What differentiates immigrant and native workers most, though, is the very low employment of immigrants in top occupations (managers and specialists) and a relatively very high share of persons employed in bottom occupations where specific skills are not required. Only $8 \%$ of immigrants worked as managers or specialists while $56 \%$ were employed in bottom occupations.

\subsection{Heterogeneity of average hours worked and productivity}

The aggregation method used in this paper measures the labour input in hours and approximates the value of that input by the average wages of workers. That is why the differences in average hours worked and wages of immigrants in relation to 
(a) average hours worked

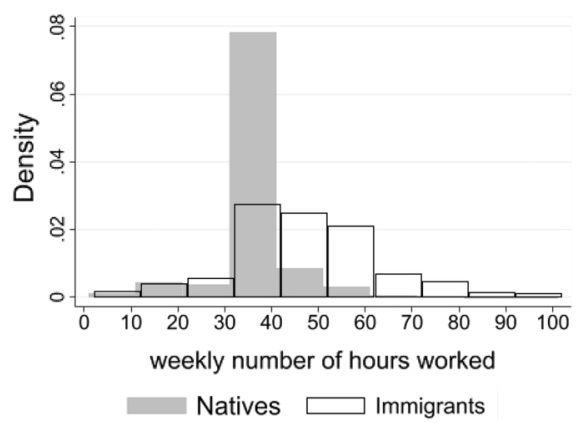

(b) average hourly wage

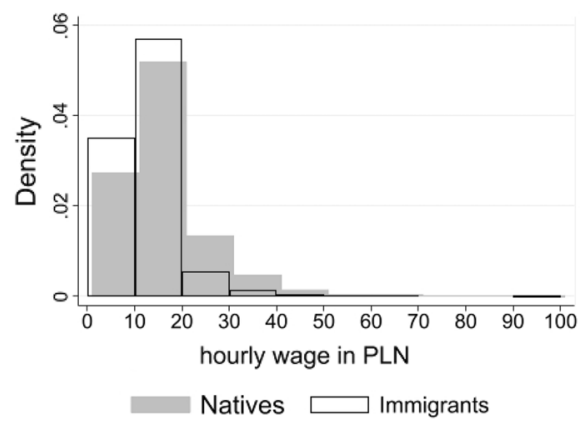

Fig. 3 Comparison of distributions of average hourly wages and average hours worked among immigrant and native workers. a Average hours worked. b Average hourly wage. Source: Own calculations

Polish workers are important not only for the total population but also in the case of the 216 groups taken into account in our analysis. Mean values of these variables among immigrants relative to native workers, broken down by gender, age, education, sector and occupation, are presented in the Table 4. Average hours worked by immigrants are markedly higher than by Polish workers but their hourly wages are lower. This discrepancy is also visible when we compare the distributions of average weekly hours worked and average hourly wages (Fig. 3a, b), and is similar to the discrepancies observed between immigrant and native worker populations in Spain and UK a decade earlier (Kangasniemi et al. 2012).

The wage gap between native and immigrant workers remains in place even after controlling for the available features of persons and their workplaces (Strzelecki 2018). Having repeated Strzelecki's analysis using our richer dataset we confirm that magnitude of the unexplained wage gap is about $10 \%$. We also find the gap to be higher in Warsaw (11-14\%) than in Wrocław and Bydgoszcz (5-12\%), and particularly Lublin, a university city in eastern Poland, where it is almost nonexistent. The unexplained wage gap can be considered as a measure of lower productivity of immigrant workers in comparison to native workers unexplained by their measurable characteristics, reflecting, e.g., instability of contracts, lower firm- and task-specific human capital, imperfect applicability of knowledge gained abroad to nominally the same occupations in the host country, or linguistic barriers to communication. However, the unexplained wage gap can also reflect the magnitude of systematic wage discrimination, which would have different implications for growth accounting. In the baseline scenario, we assume that the average wage gap of $10 \%$ between native and immigrant workers with the same features reflects lower productivity of immigrants, but we also consider a robustness check in which the gap reflects pure wage discrimination, so that the productivity of natives and immigrants with the same features is assumed identical despite the observed difference in wages.

Apart from the uncertainty about the existence and scale of the productivity gap between native and immigrant workers, there is also uncertainty with regard 
Table 4 Relative wages and relative hours worked of immigrants in comparison to native workers by worker characteristics

\begin{tabular}{|c|c|c|}
\hline Variable & $\begin{array}{l}\text { Relative hours } \\
\text { worked }\end{array}$ & $\begin{array}{l}\text { Relative } \\
\text { hourly } \\
\text { wages }\end{array}$ \\
\hline Total & 1.427 & 0.781 \\
\hline \multicolumn{3}{|l|}{ Gender } \\
\hline Male & 1.385 & 0.743 \\
\hline Female & 1.483 & 0.852 \\
\hline \multicolumn{3}{|l|}{ Age } \\
\hline $15-24$ & 0.888 & 0.989 \\
\hline $24-44$ & 1.445 & 0.816 \\
\hline $45-59 / 64$ & 1.356 & 0.612 \\
\hline $60 / 65+$ & 1.843 & 0.459 \\
\hline \multicolumn{3}{|l|}{ Educational attainment } \\
\hline Tertiary & 1.378 & 0.689 \\
\hline Secondary & 1.311 & 0.841 \\
\hline Basic and vocational & 1.278 & 0.974 \\
\hline \multicolumn{3}{|l|}{ Sector } \\
\hline Industry & 1.356 & 0.702 \\
\hline Agriculture and construction & 1.311 & 0.841 \\
\hline Services & 1.278 & 0.781 \\
\hline \multicolumn{3}{|l|}{ Occupation group } \\
\hline Managers and specialists & 1.052 & 0.868 \\
\hline Middle occupations & 1.231 & 0.851 \\
\hline Bottom occupations & 1.269 & 0.926 \\
\hline
\end{tabular}

Source: Own calculations based on NBP surveys and LFS

to the structure of immigrants. Our baseline decomposition is based on our best possible knowledge and takes into account the features of immigrants mentioned in Tables 3 and 4: gender, age, educational attainment, sector of employment and occupation category. Nevertheless, in order to truly understand the importance of the heterogeneity of immigrants it seems necessary to check also four scenarios where the assumptions about the differences between natives and immigrants are partially relaxed:

(a) same hours - in which the average hours worked of all groups of immigrants are exactly the same as for native workers,

(b) same structure - in which average hours worked and wages are different but the proportions of groups defined by the features are the same as for natives,

(c) same wages - where hours worked and features of immigrants are different but wages of persons with certain features are always the same as among natives. This is a scenario that interprets the unexplained wage gap as pure discrimination, 
(d) all equal-where features of immigrants, their working hours and wages are exactly the same as among natives. This scenario interprets both the explained and unexplained wage gap as pure discrimination.

The last scenario can also be interpreted as a 'naive' counterfactual where all labour input growth due to immigration is attributed to the additional employment of immigrants as if only the headcount mattered.

\section{Results}

We will now present the results of our study. We first present our estimates of the contribution of Ukrainian immigrants to the total labour supply in Poland in the baseline scenario, comparing it with a null scenario that disregards the labour of immigrant workers. Next, we discuss the impact of imputed immigrant labour on Polish GDP growth. Details of robustness checks regarding (i) the estimated number of immigrants and (ii) differences between immigrants and natives in terms of hours worked, hourly wages, and socio-economic structure, have been relegated to the "Appendix".

\subsection{Labour input in the baseline scenario vs. the null scenario without immigration}

Our baseline estimates of the labour input, which take into account both the quantity and productivity of hours worked, confirm a large positive impact of immigration from Ukraine on the total labour supply in Poland in 2013-2018 (Fig. 4, Table 5). Although growth in the labour input of the native Polish population has slowed down considerably after 2014, immigration filled most of the ensuing gap, sustaining labour input growth rates above 2\% per annum until 2017 and cushioning a major part of the decline in 2018. Decomposition of this result shows that the impact of the growing number of immigrant employees was particularly important in the years 2014-2017 when it added 0.5-1.3 pp. to annual labour input growth in Poland (Fig. 5). On top of that, relatively longer average working hours of immigrant workers contributed an additional $0.1-0.3 \mathrm{pp}$. per annum. The structural make-up and average productivity of the immigrant labour force, in turn, corrected the overall impact downwards by about $0.1-0.3 \mathrm{pp}$. per annum. At the same time, the average annual growth rate of employment among native workers amounted to $1.1 \%$ while their average hours worked per worker decreased annually on average by $0.4 \%$.

A further decomposition allows observing which features of all workers (Fig. 6a) and immigrants (Fig. 6b) have been most important for determining the contribution of their structure to overall (productivity-adjusted) labour supply growth. We find that the slightly negative contribution of the socio-demographic structure of the immigrant worker population is primarily due to the fact that Ukrainians are heavily overrepresented in bottom occupations and underrepresented in the group of managers and specialists (Fig. 6b). Another important 


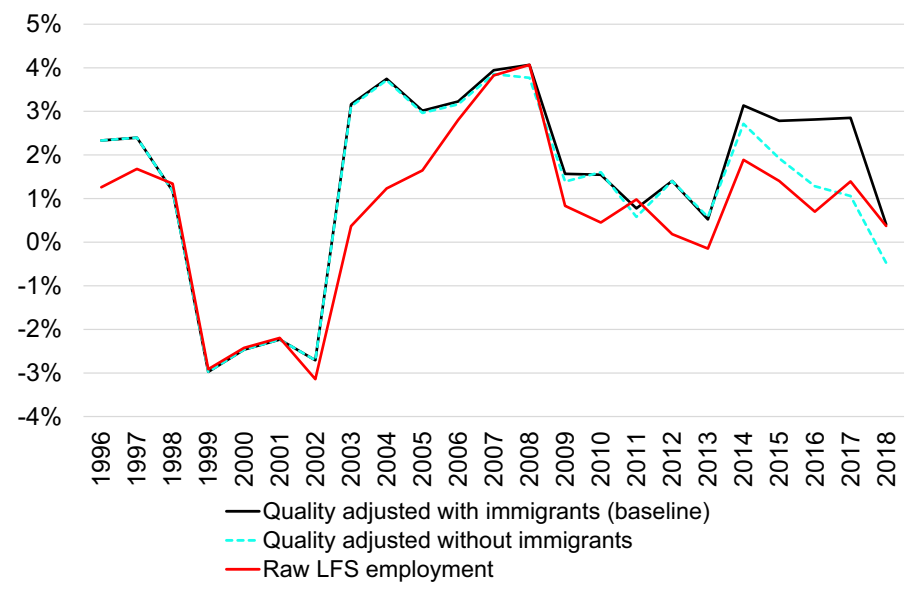

Fig. 4 Annual labour input growth-effects of including additional information. Source: Own calculations. Raw LFS employment does not contain temporary immigrants, quality adjustment and hours worked

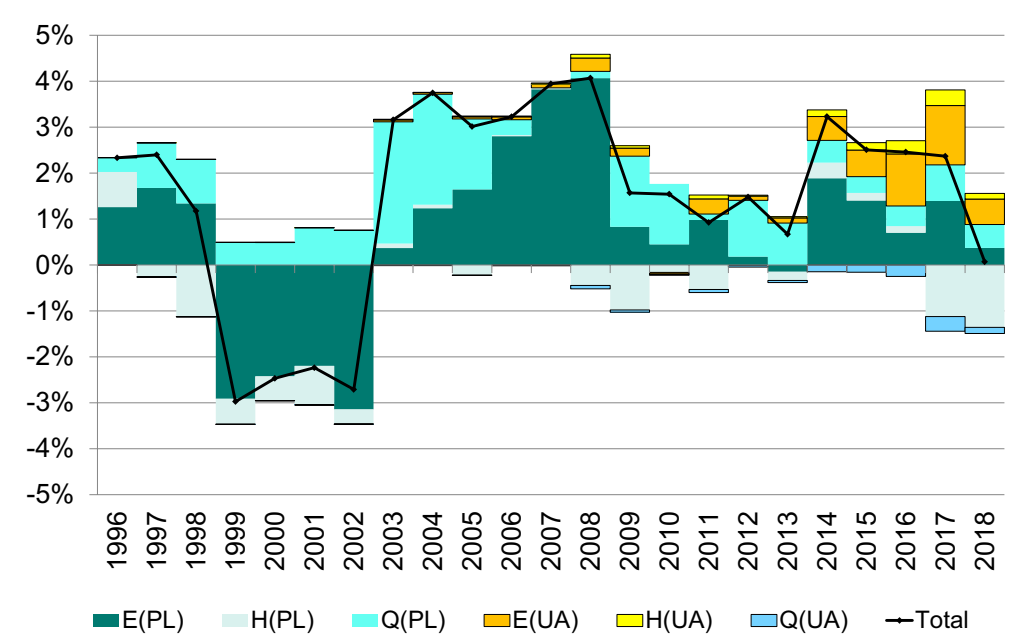

Fig. 5 Annual labour input growth-decomposition of baseline. Source: Own calculations. $E$ number of employees; $H$ hours worked per employee, $Q$ composition of hours worked. $P L$ Polish workers, $U A$ Ukrainian workers

contribution comes from the relatively lower average age of Ukrainian workersas general rule wages of younger persons tend to be lower. After controlling for occupational structure and age, though, other features of immigrants like their relatively high educational attainment had a very limited positive impact despite the fact that on average formal educational attainment among immigrants has been noticeably greater than among Polish workers (Table 3). These results are generally well aligned with the predictions of the theory of immigrant surplus in an economy with different types of labour (Borjas 2019). 
Table 5 Decomposition of annual growth rates of the labour input in the period $2013 *-2018$ (in \%)

\begin{tabular}{llllllll}
\hline Year & Total & E (PL) & H( PL) & Q (PL) & E (UA) & H (UA) & Q (UA) \\
\hline 2014 & 3.2 & 1.9 & 0.3 & 0.5 & 0.5 & 0.1 & -0.1 \\
2015 & 2.5 & 1.4 & 0.2 & 0.4 & 0.6 & 0.2 & -0.2 \\
2016 & 2.5 & 0.7 & 0.1 & 0.4 & 1.1 & 0.3 & -0.2 \\
2017 & 2.4 & 1.4 & -1.1 & 0.8 & 1.3 & 0.3 & -0.3 \\
2018 & 0.1 & 0.4 & -1.4 & 0.5 & 0.6 & 0.1 & -0.1 \\
Average* & 2.1 & 1.1 & -0.4 & 0.5 & 0.8 & 0.2 & -0.2 \\
\hline
\end{tabular}

Source: Own calculations, *The average growth rate in the last five years, the year 2013 is treated as the base year, $E$ number of employees, $H$ hours worked per employee, $Q$ composition of hours worked, $P L$ Polish workers, UA Ukrainian workers

(a) all employees

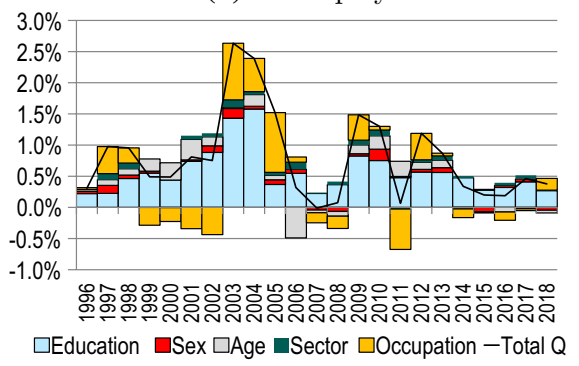

(b) only immigrants

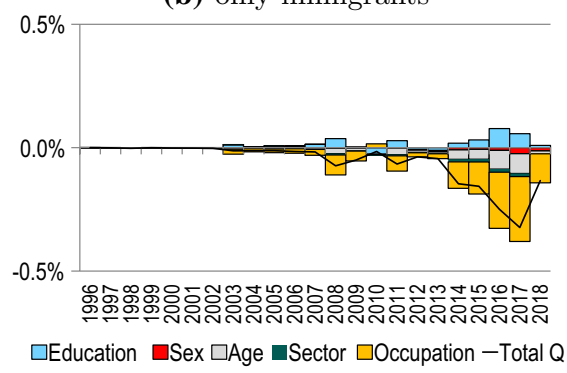

Fig. 6 Decomposition of the impact of heterogeneity of employees on labour quality growth (Total Q). Source: Own calculations. a All employees; b Only immigrants

When including also the structure and productivity of the native population in the decomposition (Fig. 6a), our results are in good agreement with Gradzewicz et al. (2018). We confirm that the increasing educational attainment of Polish workers due to the replacement of older and less educated generations by new better educated generations provided a key contribution to overall labour supply growth in 1995-2018. A smaller positive contribution was also provided by the age component, reflecting primarily population ageing, as well as the reform of early pensions in 2009 and the gradual extension of the retirement age until 2017. A new finding of the current study pertains to the impact of the relocation of employees between occupations, related to structural changes in the economy. In general, the impact of this factor was positive over the last 25 years but there were also isolated periods of negative changes probably related to higher labour demand for low skilled workers. ${ }^{14}$

\footnotetext{
${ }^{14}$ Following the Russian crisis in 1998, Polish exporting firms were forced to re-orientate from from Eastern to Western markets. This shift required a restructuring of the economy and resulted in a period of very high unemployment (years 2000-2002). At that time also the contribution of occupational structure to productivity-adjusted labour supply growth was negative. Negative contributions of occupational structure were observed also during booms in the construction sector (years 2007-2008 and 2011) when dynamic wage growth in relatively less skilled jobs in this sector attracted employees from other occupations.
} 


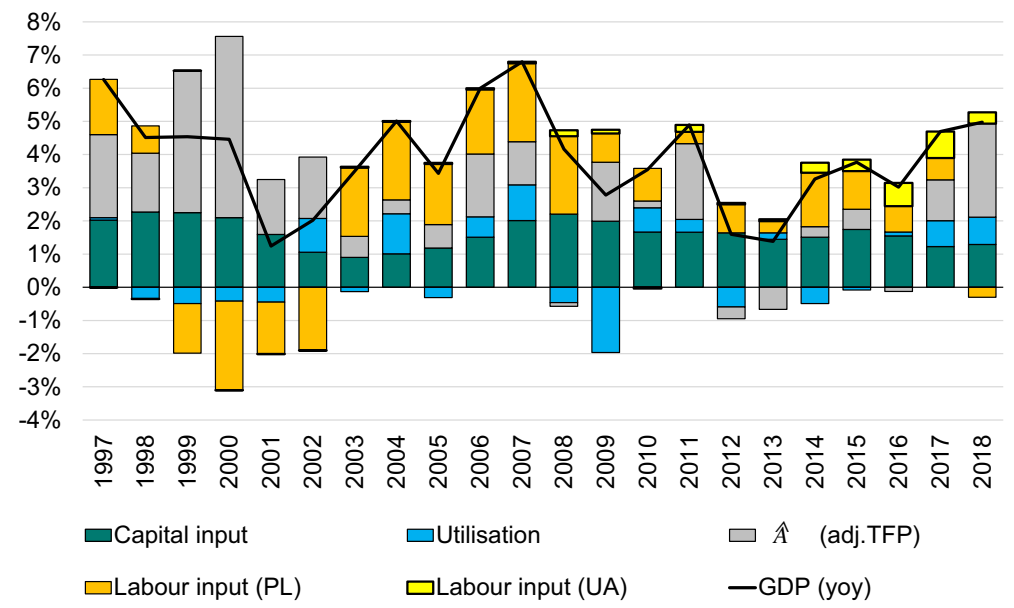

Fig. 7 Decomposition of GDP growth including the distinction between contributions of the native (PL) and immigrant (UA) workforce. Source: Own calculations

\subsection{Growth accounting with immigration}

Our estimates of the labour input presented in the previous section will now be plugged in growth accounting. As argued before, until 2014 the impact of immigration on GDP growth in Poland remained negligible (below 0.1 pp., Fig. 7). Since 2014 the contribution of the labour input of immigrants rapidly grew, though, becoming a significant part of Poland's growth potential. In the period 2013-2018 the contribution of the inflow of Ukrainian workers to Poland's GDP growth ranged between $0.3 \mathrm{pp}$. to $0.8 \mathrm{pp}$. per annum ( $0.5 \mathrm{pp}$. per annum on average), so that the inflow of Ukrainian workers was responsible for about $13 \%$ of economic growth in Poland in 2013-2018. In fact in 2016-18 growth in the labour input of immigrants contributed to GDP growth more than the impact of growth in the labour input of Polish citizens.

Looking at a longer time frame, the aggregate contribution of Ukrainian immigrants to Poland's GDP growth (Tables 6, 7 and Appendix Table 11) in the entire period 1996-2018 amounted to about 4\%, compared to the contribution of labour input of Polish workers of about $18 \%$. However when we focus only on the recent years (2013-2018), the contributions of immigrants and natives are almost at par: about $13 \%$ of total economic growth was due to immigrant labour input growth while about $14 \%$ was due to labour input growth of natives. Table 7 also demonstrates that over the period 2013-2018, when Poland witnessed an unprecedented 
Table 6 Contributions of main factors to economic growth in Poland (in \%)

\begin{tabular}{llllll}
\hline & $1996^{*}-2018$ & & & \multicolumn{2}{l}{$2013^{*}-2018$} \\
\cline { 6 - 6 } \cline { 5 - 6 } & $\begin{array}{l}\text { Without } \\
\text { immigrants }\end{array}$ & Baseline & & $\begin{array}{l}\text { Without } \\
\text { immigrants }\end{array}$ & Baseline \\
\hline $\mathrm{K}$ & 41.8 & 41.8 & & 35.3 & 35.3 \\
L (PL) & 17.9 & 17.9 & & 13.9 & 13.9 \\
L (UA) & 0.0 & 3.8 & & 0.0 & 13.3 \\
Util & 1.5 & 1.5 & & 9.9 & 9.9 \\
A** & 38.8 & 35.1 & & 40.9 & 27.6 \\
\hline
\end{tabular}

Source: Own calculations

*Base year, **Capacity utilisation-adjusted TFP

Table 7 Decomposition of annual GDP growth (in pp.) in the baseline scenario, 2013*-2018

\begin{tabular}{lclclcc}
\hline Year & GDP (yoy) & Capital input & Labour input (PL) & $\begin{array}{l}\text { Labour } \\
\text { input (UA) }\end{array}$ & Utilisation & A $^{* * *}$ \\
\hline 2014 & 3.3 & 1.5 & 1.6 & 0.3 & -0.5 & 0.3 \\
2015 & 3.8 & 1.7 & 1.1 & 0.3 & -0.1 & 0.6 \\
2016 & 3.0 & 1.5 & 0.8 & 0.7 & 0.1 & -0.1 \\
2017 & 4.7 & 1.2 & 0.7 & 0.8 & 0.8 & 1.2 \\
2018 & 5.0 & 1.3 & -0.3 & 0.3 & 0.8 & 2.8 \\
Average* & 3.9 & 1.5 & 0.8 & 0.5 & 0.2 & 1.0 \\
Cumulative** & 21.3 & 7.5 & 4.0 & 2.5 & 1.1 & 4.9 \\
\hline
\end{tabular}

Source: Own calculations

*The average growth rate in the last five years, the year 2013 is treated as the base year, **Cumulative growth in the period 2013-2018, ***Capacity utilisation-adjusted TFP

inflow of immigrant workers from Ukraine, Polish GDP grew by $21.3 \%$ with arriving immigrants contributing $2.5 \mathrm{pp}$. to this growth. As substantial as it looks in the short run, this contribution is diluted in the long run, though, because the wave of immigration was so short. Over the entire period 1996-2018 Polish GDP more than doubled (131.6\% cumulative GDP growth), but the contribution of immigrant workers to this growth was only $3.3 \mathrm{pp}$.

Our baseline estimates are of course subject to uncertainty, both in terms of the actual number of immigrant workers from Ukraine in Poland, and their structure and productivity. However, as demonstrated in Table 8 and Fig. 8 with details in the Appendix, these results are actually quite robust to the changes in the assumed structure of immigrants as the lower skilled jobs of immigrants are usually accompanied by the longer working hours. We also find that the extent of pure wage discrimination of immigrant workers has only minor influence on the measured contributions of immigrant labour growth to GDP growth. Table 8 demonstrates in particular that the possible magnitude of impact ranges from about $9 \%$ of GDP growth in 2013-2018 in our most conservative scenario (baseline minus 20\% immigration) 
Table 8 Robustness of the results-contributions of main factors to economic growth in Poland (in \%)

\begin{tabular}{lclcl}
\hline \multicolumn{5}{c}{$2013^{*}-2018$} \\
\cline { 2 - 5 } & Baseline & $\begin{array}{l}\text { Alter- } \\
\text { native } \\
\text { scenario }\end{array}$ & Baseline - 20\% & Baseline + 20\% \\
\hline K & 35.3 & 35.3 & 35.3 & 35.3 \\
L (PL) & 13.9 & 13.9 & 13.9 & 13.9 \\
L (UA) & 13.3 & 18.7 & 8.9 & 15.8 \\
Util & 9.9 & 9.9 & 9.9 & 9.9 \\
A** & 27.6 & 22.2 & 31.9 & 25.1 \\
\hline
\end{tabular}

Source: Own calculations

*Base year, **Capacity utilisation-adjusted TFP (a) Contribution of immigration to GDP growth

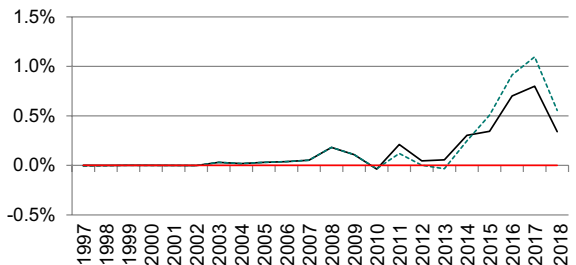

-With quality adjustment and migration (baseline)

--- with quality adjustement and migration (alternative)

-With quality adjustment, without imigration (b) Capacity utilisation-adjusted TFP growth under different migration scenarios

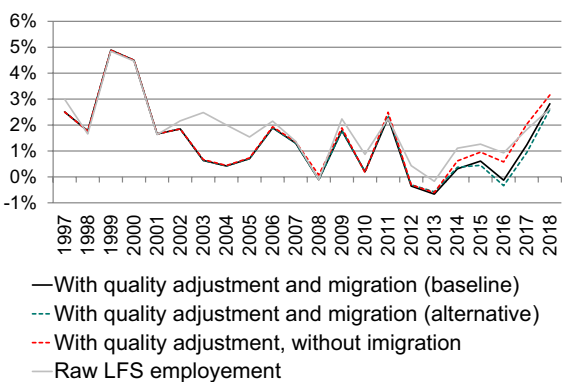

Fig. 8 Impact of the correction of the labour input in the Polish economy on annual growth of GDP and TFP. a Contribution of immigration to GDP growth. b Capacity utilisation-adjusted TFP growth under different migration scenarios. Source: Own calculations

to $19 \%$ in our alternative scenario outlined in the previous section. As documented in the Appendix Table 12, bulk of the difference is realized in the period of most dynamic immigration, 2015-2017, and outside of the time bracket 2013-2018 the contribution of immigrant labour to Poland's GDP growth was very small across all scenarios, ranging from zero to at most $0.2 \mathrm{pp}$. per annum.

Imputation of the labour input of immigrants has important consequences for the assessment of capacity utilisation-adjusted total factor productivity $(A)$ growth in the Polish economy which is computed residually. According to our baseline findings, in 2013-2018 the contribution of adjusted TFP growth to GDP growth amounted probably not $41 \%$ (which would be obtained if the labour of Ukrainian immigrants were disregarded) but about 28\%. In the whole period 1996-2018, after our imputations, the contribution of adjusted TFP growth is corrected downwards from 39 to $35 \%$.

This means that having factored in the contribution of immigrant workers from Ukraine, the last five years were in fact characterized not by above-average, but below-average contribution of capacity utilisation-adjusted TFP to economic growth 
Table 9 Contribution of Ukrainian immigrants to growth in GDP per worker and GDP per native worker

\begin{tabular}{lccccc}
\hline & \multicolumn{2}{c}{$1996 *-2018$} & & \multicolumn{2}{l}{$2013 *-2018$} \\
\cline { 2 - 3 } & pp. & $\%$ & & pp. & $\%$ \\
\hline GDP per worker (yoy) & 2.5 & & & 1.8 & \\
L (PL) & -0.4 & $-17 \%$ & -0.5 & $-27 \%$ \\
L (UA) & -0.1 & $-4 \%$ & -0.3 & $-17 \%$ \\
GDP per native worker (yoy) & 2.8 & & 2.7 & \\
L (PL) & -0.4 & $-16 \%$ & -0.5 & $-19 \%$ \\
L (UA) & 0.1 & $5 \%$ & 0.5 & $19 \%$ \\
\hline
\end{tabular}

Source: Own calculations

*Base year

in Poland. In reality, recent growth was in fact much more labour-intensive, and much less technology-driven than previously interpreted. In 2013-2015 the contribution of adjusted TFP growth to GDP growth was very low at below $1 \mathrm{pp}$. per annum, in 2015-2016 it was none at all, and it picked up only in the last two years, 2017-2018 (Fig. 8).

\subsection{Contribution to growth in GDP per worker}

Thus far we have computed the contributions of labour of Ukrainian immigrants to aggregate GDP growth in Poland. An interesting related question is, however, how these new arriving workers contributed to growth in GDP per worker and GDP per native worker. Such contributions can be straightforwardly computed from our growth accounting setup. Namely, using equations (2) and (8) we obtain the following decomposition of growth in GDP per worker:

$$
\begin{aligned}
\hat{Y}-\hat{L} & =\alpha \hat{K}-\alpha \hat{L}+\widehat{U t i l}+\hat{A}= \\
& =\alpha \hat{K}-\alpha\left(\hat{L}_{\text {raw }}^{P L}+\hat{L}_{\text {raw }}^{U A}+\hat{Q}_{L}^{P L}+\hat{Q}_{L}^{U A}\right)+\widehat{U t i l}+\hat{A} .
\end{aligned}
$$

GDP per native worker, in turn, can be decomposed as:

$$
\hat{Y}-\hat{L}^{P L}=\alpha \hat{K}-\alpha\left(\hat{L}_{\text {raw }}^{P L}+\hat{Q}_{L}^{P L}\right)+(1-\alpha)\left(\hat{L}_{\text {raw }}^{U A}+\hat{Q}_{L}^{U A}\right)+\widehat{U t i l}+\hat{A} .
$$

Hence, the contribution of immigrant workers to growth in GDP per native worker (in percentage points) is exactly equal to their contribution to aggregate GDP, whereas their contribution to growth in GDP per worker has an opposite sign as immigrant workers now also enter the denominator of the considered output measure. Contributions of capital and TFP remain unchanged.

The results are presented in Table 9. These results confirm that in 2013-2018 economic growth in Poland was in fact much more labour-intensive than previously interpreted. GDP growth per worker, which factors in the inflow of immigrants, grew on average $0.9 \mathrm{pp}$. slower than GDP per native worker. Immigrant workers from Ukraine were responsible for $19 \%$ of the growth in GDP per native worker in 
Poland. When measured over the longer period 1996-2018 this contribution naturally declines, albeit still remains at a noticeable level of $5 \%$.

\section{Conclusions}

Large-scale immigration of Ukrainian citizens to Poland after 2013 is an unprecedented phenomenon in Poland's modern history. This paper sheds new light on one of its important effects: the impact on economic growth in Poland. Unfortunately, earlier decompositions of economic growth in Poland did not account for the inflow of immigrants, thereby systematically underestimating the contribution of the labour input and overestimating the role of TFP. This is a problem which our paper aims to rectify. We do this by imputing the labour supply of Ukrainian workers, estimated with the help of a number of auxiliary data sources. We believe this is an important contribution to the literature not only looking from the Polish or Ukrainian perspective, but also more broadly because similar problems are likely to arise also in other countries witnessing rapid immigration.

According to our baseline estimates in the peak of immigrant inflow (2016-2017) economic growth in Poland was increased by additional $0.7-0.8 \mathrm{pp}$. in each year due to immigration. More broadly, in the period 2013-2018 immigration contributed on average about 0.5 pp. per annum, or $13 \%$ of total GDP growth in the Polish economy. Estimates presented in this paper also show that when the labour input is corrected for immigration, residual TFP growth is significantly less important in explaining GDP growth. This suggests that recent growth in Poland has been in fact much more labour-intensive than previously interpreted.

By taking into account the heterogeneity of labour supply in the economy this paper also proposes a method of assessment of the role of human capital of immigrants in the host country. The method allows to take into account not only the skills of immigrants (their educational attainment, and age as a proxy for work experience) but also the level to which these skills are utilized (occupations and wages of immigrants in comparison to natives). Majority of immigrants all over the world tend to work in bottom occupations in the host countries even if they are university graduates. A similar tendency is observed in Poland; its influence on total labour input growth seems to be relatively limited, though. The simulation under the assumption that the immigrants would have the same features and the same productivity as the Polish workers resulted in a higher total labour input growth of only about $0.3 \mathrm{pp}$. in the peak year 2017 .

The analysis carried out in this paper has two main limitations. The first is the availability of reliable data about immigrants in Poland and their characteristics. The available data in this respect are rather limited and official estimates do not exist. We fill this gap with our own calculations based on different data sources, including in particular dedicated surveys carried out by NBP in four selected cities in Poland. Hopefully, in the future, the results of the Census, efforts of Statistics Poland and an improved system of registration of immigrants in Poland would result in the availability of more precise official data. Second, this paper presents a method 
of accounting for the sources of past growth but does not offer a model that would allow us to simulate the reaction of enterprises to changes in the availability of production factors. Further work is still needed to understand how firms would have coped with the problem of a shrinking native labour force in the absence of immigration, for example to what extent automation and robotization of production would have substituted for the labour of immigrants. Another area for potential future extensions of the analysis would be to compare the current immigration effects to the effects of a large wave of emigration from Poland in 2004-2008 (Hołda et al. 2011).

In our opinion estimates presented in this study are essential in the discussion about the contemporary drivers of growth in the Polish economy and the ramifications of immigration policy, both in Poland and elsewhere. We find that large-scale immigration from Ukraine was a significant factor behind Poland's dynamic economic growth in recent years. However, such a dynamic inflow of immigrants from Ukraine cannot be sustained much longer. In 2018 for the first time since 2014, the inflow of new immigrants slowed down. For one thing, population ageing is visible not only in Poland but also in other countries of our region including Ukraine and the potential for further migration is limited. Improving the economic situation in Ukraine-if taking place-should also deter decisions about emigration. Accordingly, increased availability of work in other countries such as Germany may encourage Ukrainian migrants to skip Poland and move further west. Moreover, the unstable situation of the majority of immigrant workers in Poland (Chmielewska et al. 2019) creates also a risk of their potential outflow if external conditions change.

\section{Appendix}

\section{Robustness checks with respect to the number of immigrants}

To confirm reliability of our baseline results, we have checked their sensitivity to different assumptions about the number of immigrants. The question here is, what would happen if the number of immigrants was in fact lower or higher than assumed in our baseline estimate? As mentioned earlier we consider four scenarios in this regard: baseline, an alternative scenario, and two sensitivity tests artificially shifting the baseline upwards or downwards by $20 \%$ throughout the entire path.

The results suggest (Fig. 9) that the main conclusions inferred from our baseline scenario are robust. In all scenarios except the null variant without migration, labour input growth in the period 2015-2017 remained lower than in the peak of 2014 but still above $2 \%$ and relatively stable. A slowdown was observed only in 2018. Although all scenarios show similar patterns over time, the growth rates are quantitatively different. The highest ones are observed for the alternative scenario which takes into account illegal employment of immigrants. According to this view-as well as the sensitivity test that assumes $20 \%$ higher immigration than in the baseline-immigration inflow was more than enough to counterbalance the negative impact of weak employment growth and sharp decline in average hours worked among native workers in 2018 , so that overall annual labour input growth 


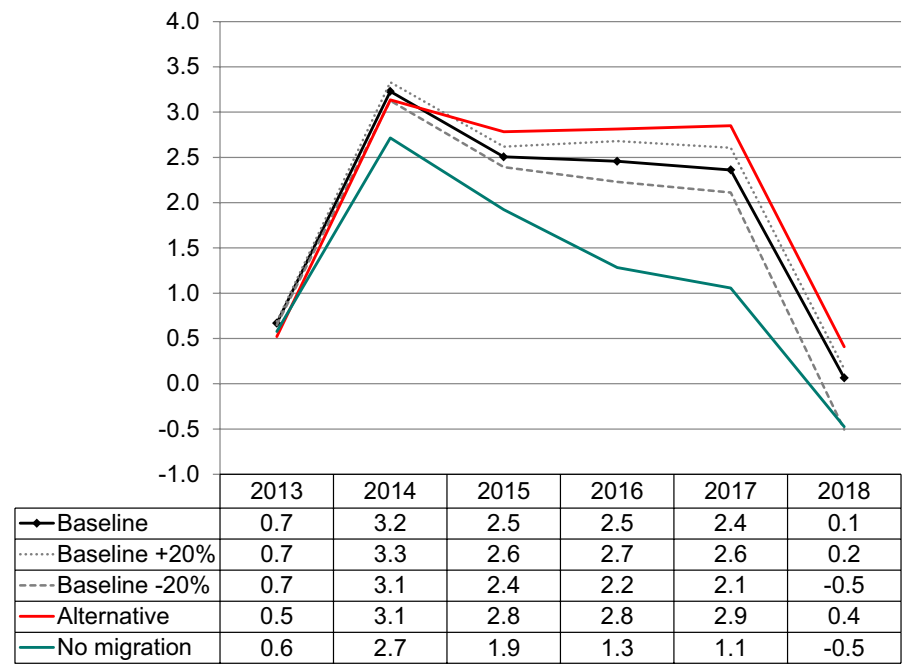

Fig. 9 Annual labour input growth under five scenarios regarding the number of immigrants. Source: Own calculations

amounted to $+0.3 \%$ in that year. In other scenarios annual labour input growth rates were closer to $2 \%$ in the period 2015-2017 and slightly negative in 2018 .

\section{The role of heterogeneity of immigrants}

The baseline scenario assumes that proportions of certain types of workers (216 groups) are different among immigrants than among natives. In addition average hours worked of immigrants are higher than of native workers but there are also large between-group differences. Finally, hourly wages of immigrants are on average lower than the wages of natives and also quite heterogeneous. In order to quantify how these assumptions influence our baseline results we have considered four scenarios where the assumptions between immigrants and natives were partially relaxed:

(a) same hours: if we assume that there are no differences between hours worked of native and immigrant workers, it leads on average to a lower impact because on average immigrants work longer hours (Fig. 10a). The main effect is however partially counterbalanced by a composition effect: total hours worked by immigrants are now a lower fraction of total hours in the economy and therefore the detrimental effect of relatively lower wages of immigrants is now lower;

(b) same structure: in comparison to Polish workers immigrants are on average younger and work in worse paid (less productive) occupations. What would 
(a) the same hours

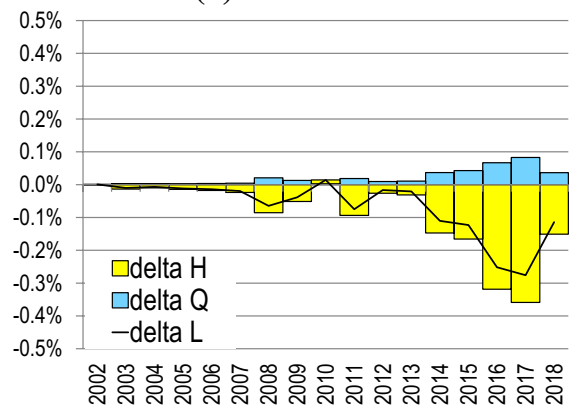

(c) the same wages

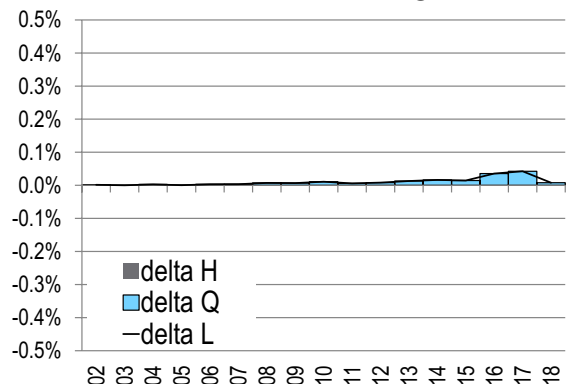

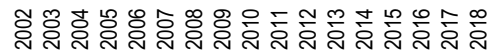

(b) the same characteristics

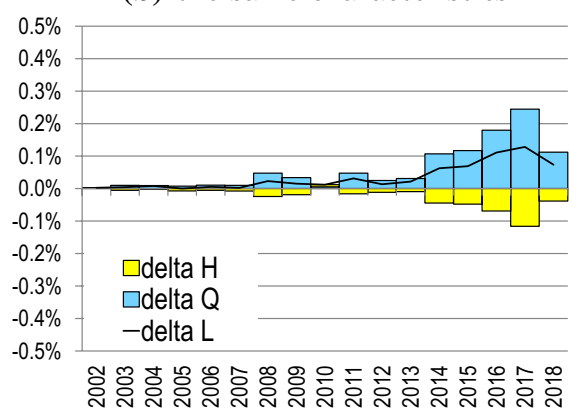

(d) all features the same

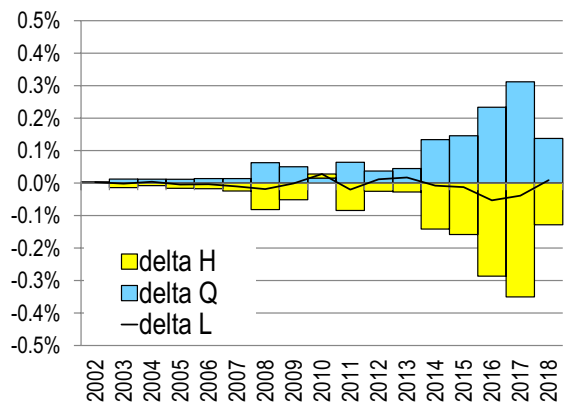

Fig. 10 Robustness checks-the impact of the suspension of differences between Ukrainian and Polish workers by selected features in comparison to the baseline with all differences included; a The same hours. b The same characteristics. $\mathbf{c}$ The same wages. $\mathbf{d}$ All features the same. Source: Own calculations

happen if the proportions of immigrants and natives in all analyzed groups were the same but differences in average hours worked and hourly wages remained intact? The labour input would then be higher due to the higher mean age of the imputed workers and their employment in more productive occupations, even though average working hours would then be slightly lower (Fig. 10b);

(c) same wages: in the baseline scenario the lower average wage of immigrants is both due to their characteristics and the unexplained native-immigrants wage gap, close to $10 \%$ on average. However what would happen if we assumed that there was no difference between Polish and immigrant workers inside the groups that describe the heterogeneity of the workforce? In other words, what if the unexplained wage gap reflected pure wage discrimination, without any unexplained productivity differences? Figure 10c suggests that the effect of this change is minuscule: a higher assessment of the productivity of immigrants in 
comparison to Polish workers in the same occupations would contribute at most $0.1 \mathrm{pp}$. per annum to overall labour supply growth;

(d) all equal: finally, we analyse the scenario in which all features of immigrants would be the same as of Polish workers and in addition in all analysed categories they would earn the same wages and work the same average number of hours. In such a scenario labour input growth would be only marginally faster than in the baseline scenario because gains in labour productivity due to a more productive workforce and better wages will be offset by lower average working hours (Fig. 10d).

\section{Additional figures and tables}

See Fig. 11, Tables 10, 11 and 12.

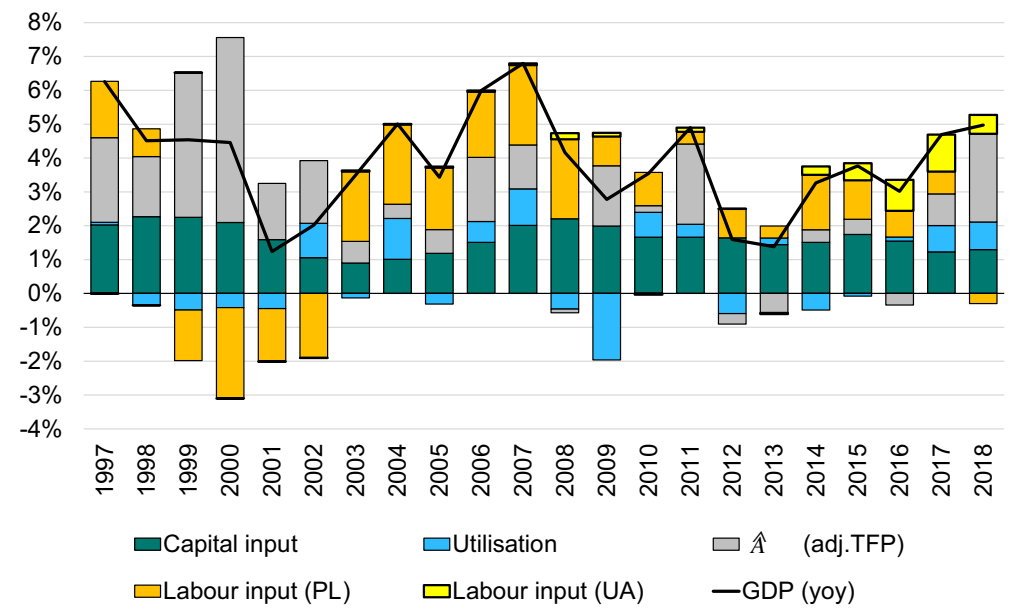

Fig. 11 Decomposition of GDP growth including the distinction between contributions of the native (PL) and immigrant (UA) workforce: alternative scenario. Source: Own calculations 
Table 10 Decomposition of annual growth of the labour input (in \%) in the baseline scenario

\begin{tabular}{|c|c|c|c|c|c|c|c|}
\hline Year & Total & $\mathrm{E}(\mathrm{PL})$ & $\mathrm{H}(\mathrm{PL})$ & $\mathrm{Q}(\mathrm{PL})$ & $\mathrm{E}$ (UA) & H (UA) & $\mathrm{Q}(\mathrm{UA})$ \\
\hline 1996 & 2.3 & 1.3 & 0.8 & 0.3 & 0.0 & 0.0 & 0.0 \\
\hline 1997 & 2.4 & 1.7 & -0.3 & 1.0 & 0.0 & 0.0 & 0.0 \\
\hline 1998 & 1.2 & 1.3 & -1.1 & 1.0 & 0.0 & 0.0 & 0.0 \\
\hline 1999 & -3.0 & -2.9 & -0.6 & 0.5 & 0.0 & 0.0 & 0.0 \\
\hline 2000 & -2.5 & -2.4 & -0.5 & 0.5 & 0.0 & 0.0 & 0.0 \\
\hline 2001 & -2.2 & -2.2 & -0.9 & 0.8 & 0.0 & 0.0 & 0.0 \\
\hline 2002 & -2.7 & -3.1 & -0.3 & 0.8 & 0.0 & 0.0 & 0.0 \\
\hline 2003 & 3.2 & 0.4 & 0.1 & 2.6 & 0.0 & 0.0 & 0.0 \\
\hline 2004 & 3.7 & 1.2 & 0.1 & 2.4 & 0.0 & 0.0 & 0.0 \\
\hline 2005 & 3.0 & 1.6 & -0.2 & 1.5 & 0.0 & 0.0 & 0.0 \\
\hline 2006 & 3.2 & 2.8 & 0.0 & 0.3 & 0.1 & 0.0 & 0.0 \\
\hline 2007 & 3.9 & 3.8 & 0.0 & 0.0 & 0.1 & 0.0 & 0.0 \\
\hline 2008 & 4.1 & 4.1 & -0.4 & 0.1 & 0.3 & 0.1 & -0.1 \\
\hline 2009 & 1.6 & 0.8 & -1.0 & 1.5 & 0.2 & 0.0 & 0.0 \\
\hline 2010 & 1.5 & 0.4 & -0.2 & 1.3 & 0.0 & 0.0 & 0.0 \\
\hline 2011 & 0.9 & 1.0 & -0.5 & 0.1 & 0.3 & 0.1 & -0.1 \\
\hline 2012 & 1.5 & 0.2 & 0.0 & 1.2 & 0.1 & 0.0 & 0.0 \\
\hline 2013 & 0.7 & -0.1 & -0.2 & 0.9 & 0.1 & 0.0 & 0.0 \\
\hline 2014 & 3.2 & 1.9 & 0.3 & 0.5 & 0.5 & 0.1 & -0.1 \\
\hline 2015 & 2.5 & 1.4 & 0.2 & 0.4 & 0.6 & 0.2 & -0.2 \\
\hline 2016 & 2.5 & 0.7 & 0.1 & 0.4 & 1.1 & 0.3 & -0.2 \\
\hline 2017 & 2.4 & 1.4 & -1.1 & 0.8 & 1.3 & 0.3 & -0.3 \\
\hline 2018 & 0.1 & 0.4 & -1.4 & 0.5 & 0.6 & 0.1 & -0.1 \\
\hline
\end{tabular}

Source: Own calculations

$E$ number of employees; $H$ hours worked per employee; $Q$ composition of hours worked. $P L$ Polish workers, UA Ukrainian workers. 
Table 11 Decomposition of annual GDP growth (in \%) in the baseline scenario

\begin{tabular}{|c|c|c|c|c|c|c|}
\hline Year & GDP (yoy) & Capital input & Labour input (PL) & $\begin{array}{l}\text { Labour } \\
\text { input (UA) }\end{array}$ & Utilisation & $\hat{A}^{*}$ \\
\hline 1997 & 6.3 & 2.0 & 1.7 & 0.0 & 0.1 & 2.5 \\
\hline 1998 & 4.5 & 2.3 & 0.8 & 0.0 & -0.3 & 1.8 \\
\hline 1999 & 4.5 & 2.3 & -1.5 & 0.0 & -0.5 & 4.3 \\
\hline 2000 & 4.5 & 2.1 & -2.7 & 0.0 & -0.4 & 5.5 \\
\hline 2001 & 1.2 & 1.6 & -1.6 & 0.0 & -0.4 & 1.7 \\
\hline 2002 & 2.0 & 1.1 & -1.9 & 0.0 & 1.0 & 1.9 \\
\hline 2003 & 3.5 & 0.9 & 2.1 & 0.0 & -0.1 & 0.6 \\
\hline 2004 & 5.0 & 1.0 & 2.4 & 0.0 & 1.2 & 0.4 \\
\hline 2005 & 3.4 & 1.2 & 1.8 & 0.0 & -0.3 & 0.7 \\
\hline 2006 & 6.0 & 1.5 & 1.9 & 0.0 & 0.6 & 1.9 \\
\hline 2007 & 6.8 & 2.0 & 2.4 & 0.1 & 1.1 & 1.3 \\
\hline 2008 & 4.2 & 2.2 & 2.3 & 0.2 & -0.5 & -0.1 \\
\hline 2009 & 2.8 & 2.0 & 0.9 & 0.1 & -2.0 & 1.8 \\
\hline 2010 & 3.5 & 1.7 & 1.0 & 0.0 & 0.7 & 0.2 \\
\hline 2011 & 4.9 & 1.7 & 0.4 & 0.2 & 0.4 & 2.3 \\
\hline 2012 & 1.6 & 1.6 & 0.9 & 0.0 & -0.6 & -0.4 \\
\hline 2013 & 1.4 & 1.4 & 0.4 & 0.1 & 0.2 & -0.7 \\
\hline 2014 & 3.3 & 1.5 & 1.6 & 0.3 & -0.5 & 0.3 \\
\hline 2015 & 3.8 & 1.7 & 1.1 & 0.3 & -0.1 & 0.6 \\
\hline 2016 & 3.0 & 1.5 & 0.8 & 0.7 & 0.1 & -0.1 \\
\hline 2017 & 4.7 & 1.2 & 0.7 & 0.8 & 0.8 & 1.2 \\
\hline 2018 & 5.0 & 1.3 & -0.3 & 0.3 & 0.8 & 2.8 \\
\hline
\end{tabular}

Source: Own calculations

*Capacity utilisation-adjusted TFP 
Table 12 Comparison of contributions of the labour input of immigrants to annual GDP growth (in \%) in different scenarios

\begin{tabular}{|c|c|c|c|c|c|}
\hline Year & Baseline & $\begin{array}{l}\text { Alternative } \\
\text { scenario }\end{array}$ & Baseline $-20 \%$ & Baseline $+20 \%$ & Like PL \\
\hline 1997 & 0.0 & 0.0 & 0.0 & 0.0 & 0.0 \\
\hline 1998 & 0.0 & 0.0 & 0.0 & 0.0 & 0.0 \\
\hline 1999 & 0.0 & 0.0 & 0.0 & 0.0 & 0.0 \\
\hline 2000 & 0.0 & 0.0 & 0.0 & 0.0 & 0.0 \\
\hline 2001 & 0.0 & 0.0 & 0.0 & 0.0 & 0.0 \\
\hline 2002 & 0.0 & 0.0 & 0.0 & 0.0 & 0.0 \\
\hline 2003 & 0.0 & 0.0 & 0.0 & 0.0 & 0.0 \\
\hline 2004 & 0.0 & 0.0 & 0.0 & 0.0 & 0.0 \\
\hline 2005 & 0.0 & 0.0 & 0.0 & 0.0 & 0.0 \\
\hline 2006 & 0.0 & 0.0 & 0.0 & 0.0 & 0.0 \\
\hline 2007 & 0.1 & 0.1 & 0.0 & 0.1 & 0.0 \\
\hline 2008 & 0.2 & 0.2 & 0.1 & 0.2 & 0.2 \\
\hline 2009 & 0.1 & 0.1 & 0.1 & 0.1 & 0.1 \\
\hline 2010 & 0.0 & 0.0 & 0.0 & 0.0 & 0.0 \\
\hline 2011 & 0.2 & 0.1 & 0.2 & 0.3 & 0.2 \\
\hline 2012 & 0.0 & 0.0 & 0.0 & 0.1 & 0.1 \\
\hline 2013 & 0.1 & 0.0 & 0.0 & 0.1 & 0.1 \\
\hline 2014 & 0.3 & 0.2 & 0.2 & 0.4 & 0.3 \\
\hline 2015 & 0.3 & 0.5 & 0.3 & 0.4 & 0.3 \\
\hline 2016 & 0.7 & 0.9 & 0.6 & 0.8 & 0.7 \\
\hline 2017 & 0.8 & 1.1 & 0.6 & 0.9 & 0.8 \\
\hline 2018 & 0.3 & 0.6 & 0.0 & 0.4 & 0.3 \\
\hline
\end{tabular}

Source: Own calculations

Like PL-scenario assuming that all characteristics of immigrants are the same as the characteristics of natives, and the number of immigrants is the same as in the baseline

Author contributions Not applicable at this moment.

Funding The authors of the paper are employed in the National Bank of Poland or SGH Warsaw School of Economics

Data availability The tables produced from the raw microdata that are used in calculations can be available. Authors do not have permission to share Polish Labour Force Survey microdata and the microdata from the NBP surveys.

Code availability The calculations have been done in STATA 14.0 and Excel. Do-files and excel files used for calculations can be available.

\section{Declarations}

Conflict of interest The authors declare that they have no conflict of interest. 
Open Access This article is licensed under a Creative Commons Attribution 4.0 International License, which permits use, sharing, adaptation, distribution and reproduction in any medium or format, as long as you give appropriate credit to the original author(s) and the source, provide a link to the Creative Commons licence, and indicate if changes were made. The images or other third party material in this article are included in the article's Creative Commons licence, unless indicated otherwise in a credit line to the material. If material is not included in the article's Creative Commons licence and your intended use is not permitted by statutory regulation or exceeds the permitted use, you will need to obtain permission directly from the copyright holder. To view a copy of this licence, visit http://creativecommons.org/licen ses/by/4.0/.

\section{References}

Aleksynska, M., \& Tritah, A. (2015). The heterogeneity of immigrants, host countries income and productivity: A channel accounting approach. Economic Inquiry, 53, 150-172.

Alesina, A., Harnoss, J., \& Rapoport, H. (2016). Birthplace diversity and economic prosperity. Journal of Economic Growth, 21, 101-138.

Barrell, R., Fitzgerald, J. D., \& Riley, R. (2010). EU enlargement and migration: Assessing the macroeconomic impacts. Journal of Common Market Studies, 48, 373-395.

Barro, R. J., \& Sala-i Martin, X. (1995). Economic Growth. McGraw-Hill.

Bell, V., Burriel-Llombart, P., \& Jones, J. (2005). A quality-adjusted labour input series for the United Kingdom (1975-2002). Working Paper No. 280, Bank of England.

Borjas, G. J. (1995). The economic benefits from immigration. Journal of Economic Perspectives, 9(2), 3-22.

Borjas, G. J. (2019). Immigration and economic growth. Working paper 25836, National Bureau of Economic Research.

Boubtane, E., Coulibaly, D., \& Rault, C. (2013). Immigration, unemployment and GDP in the host country: Bootstrap panel granger causality analysis on OECD countries. Economic Modelling, $33,261-269$.

Boubtane, E., Dumont, J.-C., \& Rault, C. (2016). Immigration and economic growth in the OECD countries 1986-2006. Oxford Economic Papers, 68(2), 340-360.

Bove, V., \& Elia, L. (2017). Migration, diversity, and economic growth. World Development, 89, 227-239.

Chiswick, B. R., Chiswick, C. U., \& Miller, P. W. (1985). Are immigrants and natives perfect substitutes in production? International Migration Review, 19(4), 674-685.

Chmielewska, I., Dobroczek, G., \& Panuciak, A. (2018). Obywatele Ukrainy pracujacy w Polsce. Narodowy Bank Polski: Technical report.

Chmielewska, I., Panuciak, A., \& Strzelecki, P. (2019). Informacja z badań ankietowych imigrantów w Bydgoszczy $i$ we Wroctawiu w 2018 i 2019 roku. Narodowy Bank Polski (NBP), Warszawa: Technical report.

Chojnicki, X., Docquier, F., \& Ragot, L. (2011). Should the US have locked heavens door? Journal of Population Economics, 24(1), 317-359.

Czubkowska, S. (2019). Smartfony policzyły Ukraińców. Ile Ukrainek planuje mieć dzieci? [badanie Selectivv]. Gazeta Wyborcza, 7.03.2019.

DAE-NBP. (2019). Inflation and economic growth projection of Narodowy Bank Polski based on the NECMOD model. March 2019.

Dolado, J., Goria, A., \& Ichino, A. (1994). Immigration, human capital and growth in the host country. Journal of Population Economics, 7(2), 193-215.

Ehrlich, I., \& Kim, J. (2015). Immigration, human capital formation and endogenous economic growth. Journal of Human Capital, 9, 518-563.

Eurostat. (2019). Residence permits for non-EU citizens: First residence permits issued in the EU member states remain above 3 million in 2018. Main beneficiaries from Ukraine and China.

Fernald, J. (2012a). A quarterly, utilization-adjusted series on total factor productivity. Working Paper 2012-19, Federal Reserve Bank of San Francisco. 
Fernald, J. (2012b). Productivity and potential output before, during, and after the great recession. Working Paper 2012-18, Federal Reserve Bank of San Francisco.

Friedberg, R. M., \& Hunt, J. (1995). The impact of immigrants on host country wages, employment and growth. Journal of Economic Perspectives, 9(2), 23-44.

Górny, A., Kaczmarczyk, P., Szulecka, M., Bitner, M., Okólski, M., Sielecka, U., \& Stefańczyk, A. (2018). Imigranci $w$ polsce $w$ kontekście uproszczonej procedury zatrudniania cudzoziemców. Ośrodek Badań nad Migracjami: Technical report.

Górny, A., Kołodziejczyk, K., Madej, K., \& Kaczmarczyk, P. (2019). Nowe obszary docelowe w migracji z ukrainy do polski. przypadek bydgoszczy i wrocławia na tle innych miast. CMR Working Paper 118/176, Ośrodek Badań nad Migracjami.

Gradzewicz, M., Growiec, J., Kolasa, M., Postek, Ł, \& Strzelecki, P. (2018). Polands uninterrupted growth performance: New growth accounting evidence. Post-Communist Economies, 30, 238-272.

Heckathorn, D. D. (1997). Respondent-driven sampling: A new approach to the study of hidden populations. Social Problems, 44(2), 174-199.

Hołda, M., Saczuk, K., Strzelecki, P., \& Wyszyński, R. (2011). Settlers and guests-Determinants of the plans of return migration from UK and Ireland to Poland in the period 2007-2009. Working paper 84, Narodowy Bank Polski.

Hulten, C. (2009). Growth accounting. NBER Working Paper 15431, National Bureau of Economic Research.

Jaumotte, F., Koloskova, K., \& Saxena, S. C. (2016). The impact of migration on income levels in advanced economies. IMF Spillover Note No. 8, International Monetary Fund.

Kane, T. \& Rutledge, Z. (2018). Immigration and economic performance across fifty U.S. States from 1980-2015. Economics working paper 18112, Hoover Institution.

Kangasniemi, M., Mas, M., Robinson, C., \& Serrano, L. (2012). The economic impact of migration: Productivity analysis for Spain and the UK. Journal of Productivity Analysis, 38, 333-343.

Lewis, E. G. (2005). Immigration, skill mix, and the choice of technique. Working Paper 05-08, Federal Reserve Bank of Philadelphia.

NBP. (2019). NBP quick monitoring survey. Economic climate in the enterprise sector. Quarterly reports. NBP Quick Monitoring Survey. 3/2019, Narodowy Bank Polski, Warsaw.

OECD. (2020). International Migration Outlook 2020. Paris: OECD Publishing.

Ortega, F. \& Peri, G. (2009). The causes and effects of international migrations: Evidence from OECD countries, 1980-2005. Working Paper 14833, National Bureau of Economic Research.

Ottaviano, G. I. \& Peri, G. (2008). Immigration and national wages: Clarifying the theory and the empirics. Working Paper 14188, National Bureau of Economic Research.

Saczuk, K. (2014). Badanie aktywności ekonomicznej ludności w polsce w latach 1995-2010. korekta danych. NBP Working Paper 301, Narodowy Bank Polski, Warszawa.

Solow, R. M. (1956). A contribution to the theory of economic growth. Quarterly Journal of Economics, 70, 65-94.

Statistics Poland (2018). Aktywność ekonomiczna ludności polski IV kw. 2017. Technical report, Statistics Poland.

Strzelecki, P. (2018). Unexplained native-immigrant wage gap in Poland in 2015-2016. Insights from the surveys in Warsaw and in Lublin. Working Papers 2018-041, SGH Warsaw School of Economics, Collegium of Economic Analysis.

Szałtys, D., Adamski, M., \& Beresewicz, M. (2018). Foreigners on the national labour market-regional approach. Statistics Poland: Technical report.

Publisher's Note Springer Nature remains neutral with regard to jurisdictional claims in published maps and institutional affiliations. 